\title{
1 Pre-clinical evaluation of antiviral activity of nitazoxanide against Sars-CoV-2
}

2 Jean-Sélim Driouich ${ }^{1}$, Maxime Cochin $^{1}$, Franck Touret $^{1}$, Paul-Rémi Petit ${ }^{1}$, Magali Gilles ${ }^{1}$, Grégory

3 Moureau $^{1}$, Karine Barthélémy ${ }^{1}$, Caroline Laprie ${ }^{2}$, Thanaporn Wattanakul ${ }^{3}$, Palang Chotsiri ${ }^{3}$, Richard M.

4 Hoglund $^{3,4}$, Joel Tarning ${ }^{3,4}$, Fanny Escudié ${ }^{5}$, Ivan Scandale ${ }^{5}$, Eric Chatelain ${ }^{5}$, Xavier de Lamballerie ${ }^{1}$,

5 Caroline Solas ${ }^{1,6}$, Antoine Nougairède ${ }^{1}$

$7 \quad{ }^{1}$ Unité des Virus Émergents (UVE: Aix-Marseille University -IRD 190-Inserm 1207), Marseille, France.

$8{ }^{2}$ Laboratoire Vet-Histo, Marseille, France

$9{ }^{3}$ Mahidol Oxford Tropical Medicine Research Unit, Faculty of Tropical Medicine, Mahidol University, 10 Bangkok, Thailand.

$11{ }^{4}$ Centre for Tropical Medicine and Global Health, Nuffield Department of Clinical Medicine, 12 University of Oxford, Oxford, United Kingdom.

$13{ }^{5}$ Drugs for Neglected Diseases initiative, Geneva, Switzerland

$14{ }^{6}$ APHM, Laboratoire de Pharmacocinétique et Toxicologie, Hôpital La Timone, Marseille, France.

\section{Abstract}

To address the emergence of SARS-CoV-2, multiple clinical trials in humans were rapidly started, including those involving an oral treatment by nitazoxanide, despite no or limited pre-clinical evidence of antiviral efficacy. In this work, we present a complete pre-clinical evaluation of the antiviral activity of nitazoxanide against SARS-CoV-2. First, we confirmed the in vitro efficacy of nitazoxanide and tizoxanide (its active metabolite) against SARS-CoV-2. Then, we demonstrated nitazoxanide activity in a reconstructed bronchial human airway epithelium model. In a SARS-CoV-2 virus challenge model in hamsters, oral and intranasal treatment with nitazoxanide failed to impair viral replication in commonly affected organs. We hypothesized that this could be due to insufficient diffusion of the drug into organs of interest. Indeed, our pharmacokinetic study confirmed that concentrations of tizoxanide in organs of interest were always below the in vitro $\mathrm{EC}_{50}$. These preclinical results suggest, if directly applicable to humans, that the standard formulation and dosage of nitazoxanide is not effective in providing antiviral therapy for Covid-19. 


\section{Introduction}

The threat of a global pandemic caused by a virus from the Coronaviridae family, which are enveloped positive-stranded RNA viruses, has been hanging over the whole world since the emergence of the severe acute respiratory syndrome coronavirus (SARS-CoV) and the Middle East respiratory syndrome (MERS-CoV). In December 2019, cases of pneumonia were reported in Wuhan, China, (1). Few months later, the causative agent was identified as a new betacoronavirus (2). Named SARS-CoV-2, this pathogen progressed worldwide to such an extent that its disease, called coronavirus disease 2019 (COVID-19), was characterized as a pandemic by the World Health Organization on March 2020 (3). COVID-19 leads to a broad spectrum of clinical syndromes, ranging from pauci-symptomatic disease to severe pneumonia and acute respiratory distress syndrome (4). To date, there are no approved small molecules targeting coronavirus viral replication.. Therefore, drug repurposing has been considered as an interesting strategy to find an active antiviral therapy against SARS-CoV-2.

Nitazoxanide (NTZ) was originally developed as an antiprotozoal agent and marketed for the treatment of Giardia and Cryptosporidium infections. In recent years, it was identified as a broadspectrum antiviral drug $(5,6)$. NTZ, and its active circulating metabolite, tizoxanide (TIZ), inhibit the replication of a wide range of RNA and DNA viruses in cell culture assays including hepatitis B, hepatitis $C$, rotavirus, norovirus, dengue, yellow fever, Japanese encephalitis virus and the human immunodeficiency virus (6-8). Its inhibitory activity against viruses inducing respiratory infections was specifically investigated (9). Notably, NTZ possesses in vitro antiviral activity against influenza virus by blocking the maturation of the viral hemagglutinin, as well as against MERS coronavirus and other coronaviruses by inhibiting expression of the viral $\mathrm{N}$ protein $(8,10-12)$.

It is thus quite naturally that this molecule was rapidly considered as a potential repurposing candidate for COVID-19 management (13-18). NTZ was one of the first molecules studied in vitro against SARS-CoV-2. One of the earliest studies on SARS-CoV-2 reported a $50 \%$ effective concentration $\left(\mathrm{EC}_{50}\right)$ of $2.12 \mu \mathrm{M}$ in Vero $\mathrm{E} 6$ cells at $48 \mathrm{~h}$ post-infection (19). Assumptions regarding the possible role of TIZ against numerous targets involved in SARS-CoV-2 pathogenesis affecting viral entry and multiplication were rapidly proposed (20). Additionally, recent findings have also demonstrated that NTZ could inhibit the TMEM16 protein, a calcium-activated ion channel involved in phospholipid transposition between the cell membranes, and block SARS-CoV-2-Spike induced syncytia (21). In addition, NTZ may have the capacity to boost host innate immune responses, 
68 also been raised about its potential ability to improve multi-organ damage and providing added value 69 to patients with comorbidities (20). Consequently, many clinical trials in human investigating the 70 efficacy and the safety of an oral treatment of NTZ alone or in combination with other anti-SARS71 CoV-2 candidates are ongoing worldwide (https://clinicaltrials.gov/; search terms: nitazoxanide | 72 Covid19).

73

74 However, a pre-clinical in vivo investigation of the activity of NTZ against SARS-CoV-2 had yet to be 75 conducted. In the present study, we first confirmed the antiviral efficacy of NTZ and TIZ in vitro 76 before investigating activity against SARS-CoV-2 using reconstituted human airway epithelium and a 77 previously described Syrian hamster model $(22,23)$. A population pharmacokinetic model was developed to compare exposure in hamsters and humans, with the aim of assessing whether the exposure to NTZ and TIZ in preclinical animal species can be achieved in humans, and whether the antiviral potency observed in vitro can be recovered in vivo. 


\section{Results}

82

\section{In vitro efficacy of nitazoxanide (NTZ)}

Using two different cell lines, the VeroE6 (ACE2 ${ }^{+} /$TMPRSS2 $^{-}$) and Caco- 2 cells $\left(\mathrm{ACE2}^{+} / \mathrm{TMPRSS2}^{+}\right.$), we 1).

A Nitazoxanide Vero E6

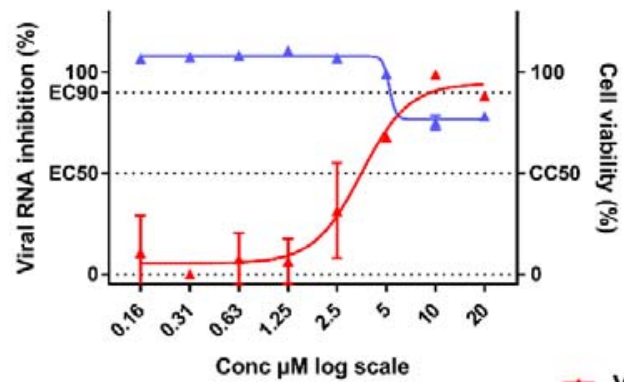

Tizoxanide Vero E6

C

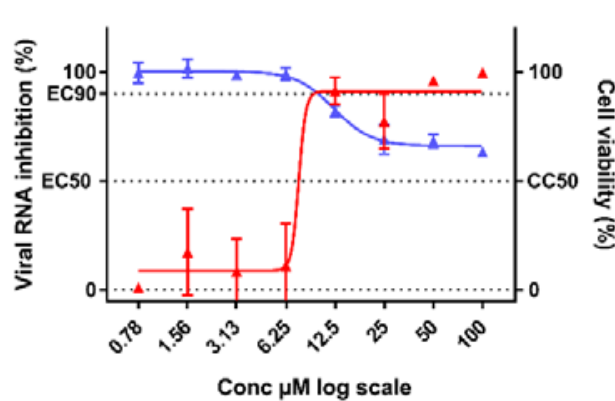

B

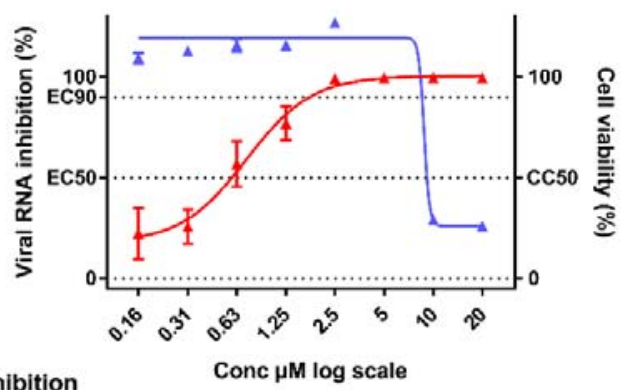

Conc $\mu \mathrm{M} \log$ scale

$\mp$ Viral RNA inhibition

$\mp$ Cell viability
92

Figure 1: Antiviral activity of NTZ and TIZ in Vero E6 and Caco-2 cells.

Dose response curve and cell viability for: NTZ in Vero E6 (a) and Caco-2 (b) cells and for TIZ in Vero E6 cells (c). D: Table of $\mathrm{EC}_{50}, \mathrm{EC}_{90}, \mathrm{CC}_{50}$. Results presented in the table for NTZ in VeroeE6 are the mean \pm SD from three independent experiments. Graphical representation is from one representative experiment.

\section{Ex vivo efficacy of NTZ}

We then investigated the ex vivo efficacy of NTZ using a recently described model of reconstituted human airway epithelial of bronchial origin (26). Five different concentrations of NTZ $(20 ; 10 ; 5 ; 2.5$; 
$1.25 \mu \mathrm{M})$ were tested in duplicate while Remdesivir, at an active concentration of $10 \mu \mathrm{M}$, was used as a positive control. The basolateral sides of the epithelia were exposed to the drugs from time of infection until day 4 post infection (dpi). Media with fresh drug were renewed at 1,2 and $3 \mathrm{dpi}$. Viral excretion was assessed at 2, 3 and $4 \mathrm{dpi}$, by measuring viral RNA yields and infectious titers at the apical side of the epithelium using quantitative real time RT-PCR and CID $_{50}$ assays, respectively. No antiviral efficacy was detected when viral excretion was assessed by quantification of viral RNA (Figure 2-A). However, at 3 and $4 \mathrm{dpi}$, a significant reduction of infectious titers was observed when concentrations of NTZ above its $\mathrm{EC}_{50}$ were used (with $\mathrm{p}$ values ranging from $0.01-0.05$ for $5 \mu \mathrm{M}, 0.001$ 0.01 for $10 \mu \mathrm{M}$ and 0.0001-0.001 for 20 $\mu \mathrm{M}$ ) (Figure 2).

A

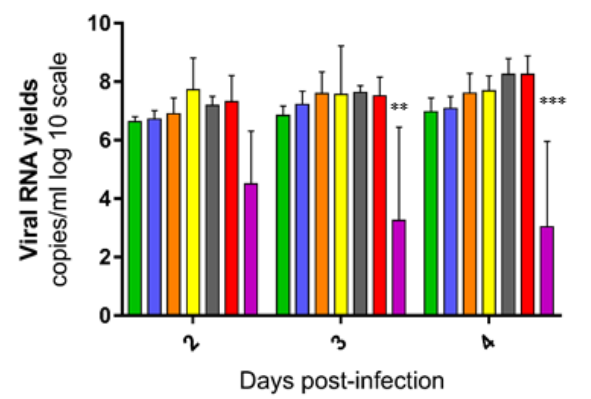

B

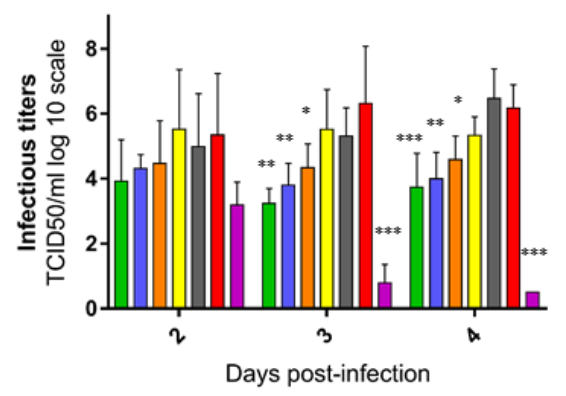

Figure 2: Antiviral activity of NTZ in a bronchial human airway epithelium. Kinetics of virus excretion at the apical side of the epithelium measured using an RT-qPCR assay $(A)$ and a TCID 50 assay $(B)$. Data represent mean \pm SD. Statistical significance was calculated by 1-way ANOVA versus untreated group. Remdesivir at $10 \mu \mathrm{M}$ was used as a positive drug control. $*, * *$ and $* * *$ indicate and average significant value lower than that of the untreated group, with a p-value ranging between $0.01-0.05,0.001-0.01$ and $0.0001-0.001$, respectively. Result are the mean \pm SD of two independent experiment with in each experiment two independent inserts.

\section{In vivo efficacy of NTZ}

Considering these results, we further investigated the potential antiviral activity of NTZ in vivo using a previously described hamster model of SARS-CoV-2 infection $(22,23,27)$.

\section{Efficacy evaluation of a NTZ oral treatment}

In a first set of experiments, we explored the antiviral efficacy of a NTZ suspension $(90 \%$ sterile distilled water, $7 \%$ of tween 80 and $3 \%$ of ethanol $80 \%$ ). During two independent experiments, groups of 6 hamsters were intranasally infected with $10^{4}$ TCID $_{50}$ of SARS-CoV-2 and received NTZ orally at doses of $500 \mathrm{mg} / \mathrm{kg} / \mathrm{day}$ BID or $750 \mathrm{mg} / \mathrm{kg} / \mathrm{day}$ TID (Figure 3a). Untreated groups of 6 hamsters received the suspension vehicle BID or TID. A group of 6 animals was treated with favipiravir (FVP) intraperitoneally $(926 \mathrm{mg} / \mathrm{kg} /$ day BID) as positive control in one experiment (22). 
133 Hamsters treated with $500 \mathrm{mg} / \mathrm{kg} /$ day BID or $750 \mathrm{mg} / \mathrm{kg} /$ day TID of NTZ for 3 days $(0,1$ and $2 \mathrm{dpi})$,

134 showed no significant differences for either infectious titers (measured using TCID $_{50}$ assay) or viral

135 RNA yields (measured using quantitative real time RT-PCR assay) in clarified lung homogenates at 3

136 dpi compared to untreated animals ( $p \geq 0.0989$ ) (Figure $3 b, 3 c, 3 f$ and $3 g$ ). No significant difference

137 was detected with regards to viral RNA yields in plasma at $3 \mathrm{dpi}(p \geq 0.4697$ ) (Figure $3 \mathrm{~d}$ and $3 \mathrm{~h}$ ).

138 Administration of FVP, however, led as expected to significant reductions of both infectious titers

139 and viral RNA yields in clarified lung homogenates $(p \leq 0.0011)$ (Figure $3 b$ and $3 c)$. NTZ-treated animals

140 showed clinical signs of illness/suffering, with their mean normalized weight becoming significantly

141 lower than that of untreated animals, at $3 \mathrm{dpi}$ for animals treated with $500 \mathrm{mg} / \mathrm{kg} / \mathrm{day}$ BID and at 2

$142 \mathrm{dpi}$ for animals treated with $750 \mathrm{mg} / \mathrm{kg} /$ day $\operatorname{TID}(p=0.0158$ and $p=0.0314$ respectively) (Figure 3e and 143 3i).

144 In another independent experiment, we tried to assess the antiviral efficacy of a longer treatment 145 period. Despite receiving $500 \mathrm{mg} / \mathrm{kg} /$ day of NTZ BID for 4 days $(0,1,2$ and $3 \mathrm{dpi})$, hamsters exhibited 146 no significant reduction at $5 \mathrm{dpi}$ of either infectious titers $(p=0.1775)$ or viral RNA ( $p=0.7003)$ yields in 147 their clarified lung homogenates, or viral RNA yields plasma ( $p=0.1305)$ (Figure 3j, 3k and 3l). 148 However, they did not show any clinical signs of illness/suffering compared to untreated animals 149 (Figure $3 \mathrm{~m})$. 
bioRxiv preprint doi: https://doi.org/10.1101/2021.12.17.473113; this version posted December 20, 2021. The copyright holder for this preprint (which was not certified by peer review) is the author/funder, who has granted bioRxiv a license to display the preprint in perpetuity. It is made available under aCC-BY 4.0 International license.
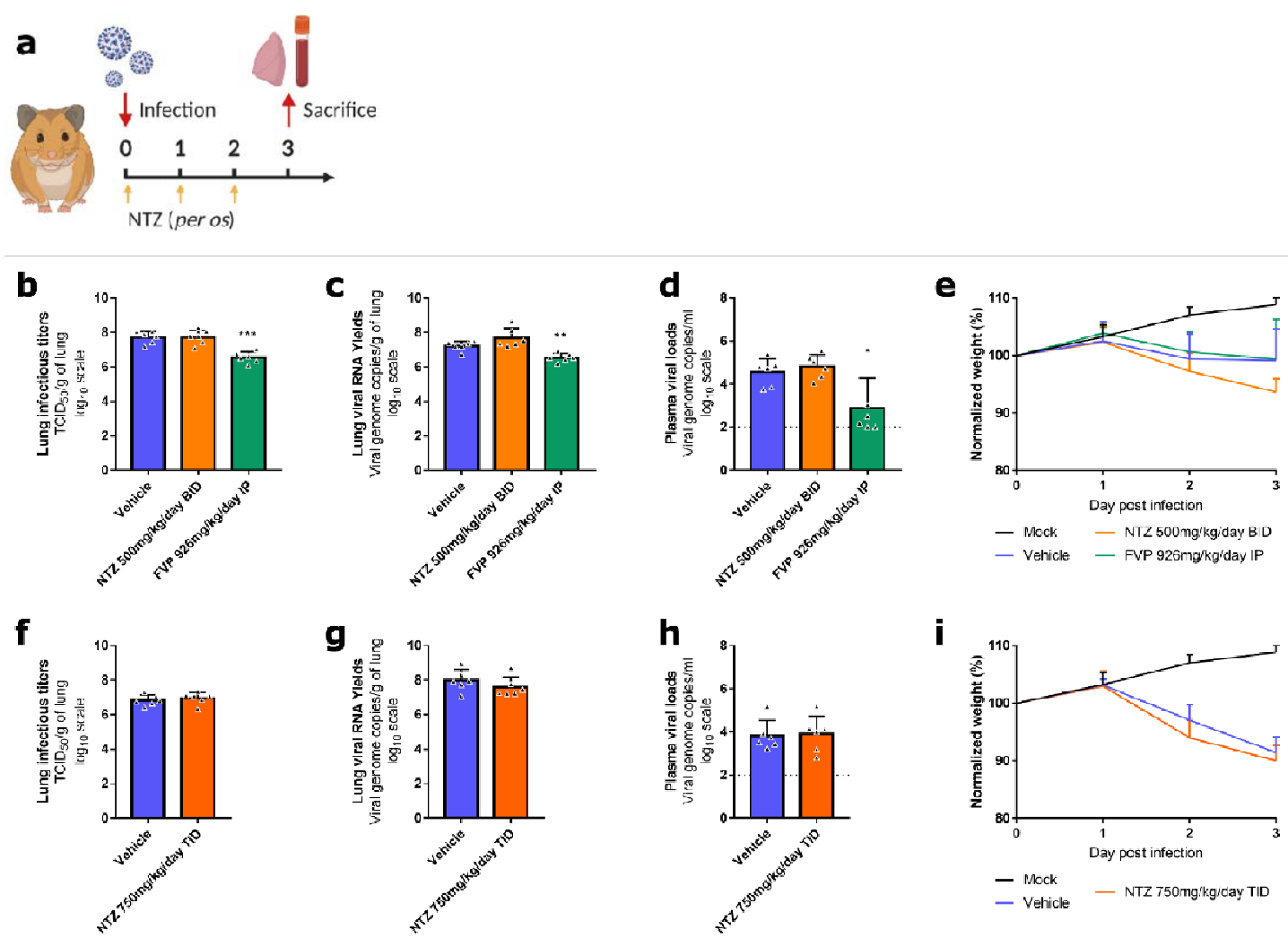

1

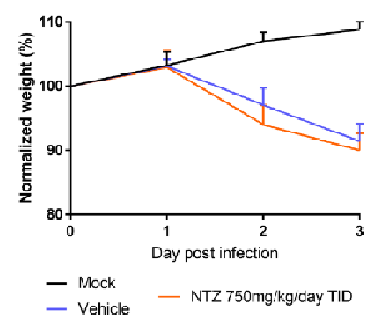

j
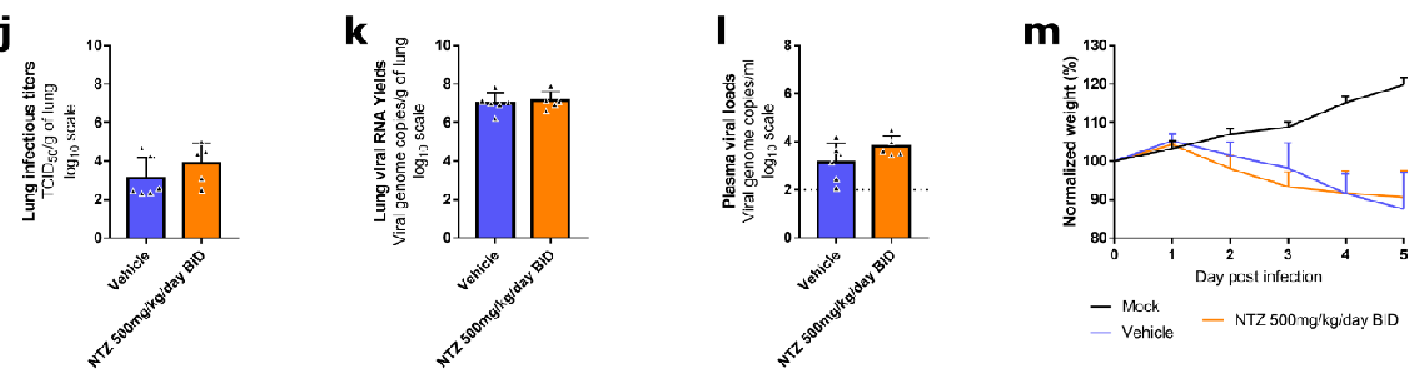

150

151

152

153

154

155

156

157

158

159

160

161

162

163

164

165

166

Figure 3: Antiviral activity of oral treatment of NTZ in a hamster model.

Groups of 6 hamsters were intranasally infected with $10^{4} \mathrm{TCID}_{50}$ of virus. a Experimental timeline. $\mathbf{b}, \mathbf{f}, \mathbf{j}$ Viral replication in lung based on infectious titers (measured using a $\mathrm{TCID}_{50}$ assay) expressed in $\mathrm{TCID}_{50} / \mathrm{g}$ of lung ( $\mathrm{n}=6$ animals/group). $\mathbf{c}, \mathbf{g}, \mathbf{k}$ Viral replication in lung based on viral RNA yields (measured using an RT-qPCR assay) expressed in viral genome copies/g of lung ( $n=6$ animals/group). $\mathbf{d}, \mathbf{h}$, I Plasma viral loads (measured using an RT-qPCR assay) are expressed in viral genome copies/mL of plasma (the dotted line indicates the detection threshold of the assay) ( $n=6$ animals/group). e, $\mathbf{i}, \mathbf{m}$ Clinical course of the disease ( $n=6$ animals/group). Normalized weight at day $n$ was calculated as follows: $\%$ of initial weight of the animal at day $n$. Data represent mean \pm SD (Details in Supplementary Data 1 ). ${ }^{* * *}$ and ${ }^{* *}$ symbols indicate that the average value for the group is significantly lower than that of the untreated group with a $p$-value ranging between $0.0001-0.001$ and $0.001-0.01$ respectively (Details in Supplementary Data 2 ).

We also explored the impact of NTZ treatment on lung pathological changes induced by SARS-CoV-2, in an independent experiment. Groups of 4 hamsters, intranasally infected with $10^{4}$ TCID $_{50}$ of SARSCoV-2, were orally treated at a dose of $500 \mathrm{mg} / \mathrm{kg} /$ day BID for 4 days $(0,1,2$ and $3 \mathrm{dpi}$ ) (Figure $4 a$ ). Untreated hamsters (group of 4 animals) received the suspension vehicle BID. Animals were sacrificed at $5 \mathrm{dpi}$ and a cumulative score from 0 to 10 (taking into account severity of inflammation, 
167 alveolar hemorrhagic necrosis and vessel lesions) was calculated and then assigned to a grade of 168 severity $(0=$ normal; $1=$ mild; $2=$ moderate; $3=$ marked and $4=$ severe; details in Supplementary Data 3 169 and 4). All animals, treated and untreated, displayed severe pulmonary impairments. Marked and 170 severe histopathological damages in lungs for both groups were identified resulting in no significant 171 difference of histopathological cumulative scores (Figure 4b). At $3 \mathrm{dpi}$, animals showed clinical signs 172 of illness/suffering, with their mean normalized weight becoming significantly lower than that of 173 untreated animals (Supplementary Fig. 1). 
bioRxiv preprint doi: https://doi.org/10.1101/2021.12.17.473113; this version posted December 20, 2021. The copyright holder for this preprint (which was not certified by peer review) is the author/funder, who has granted bioRxiv a license to display the preprint in perpetuity. It is made available under aCC-BY 4.0 International license.
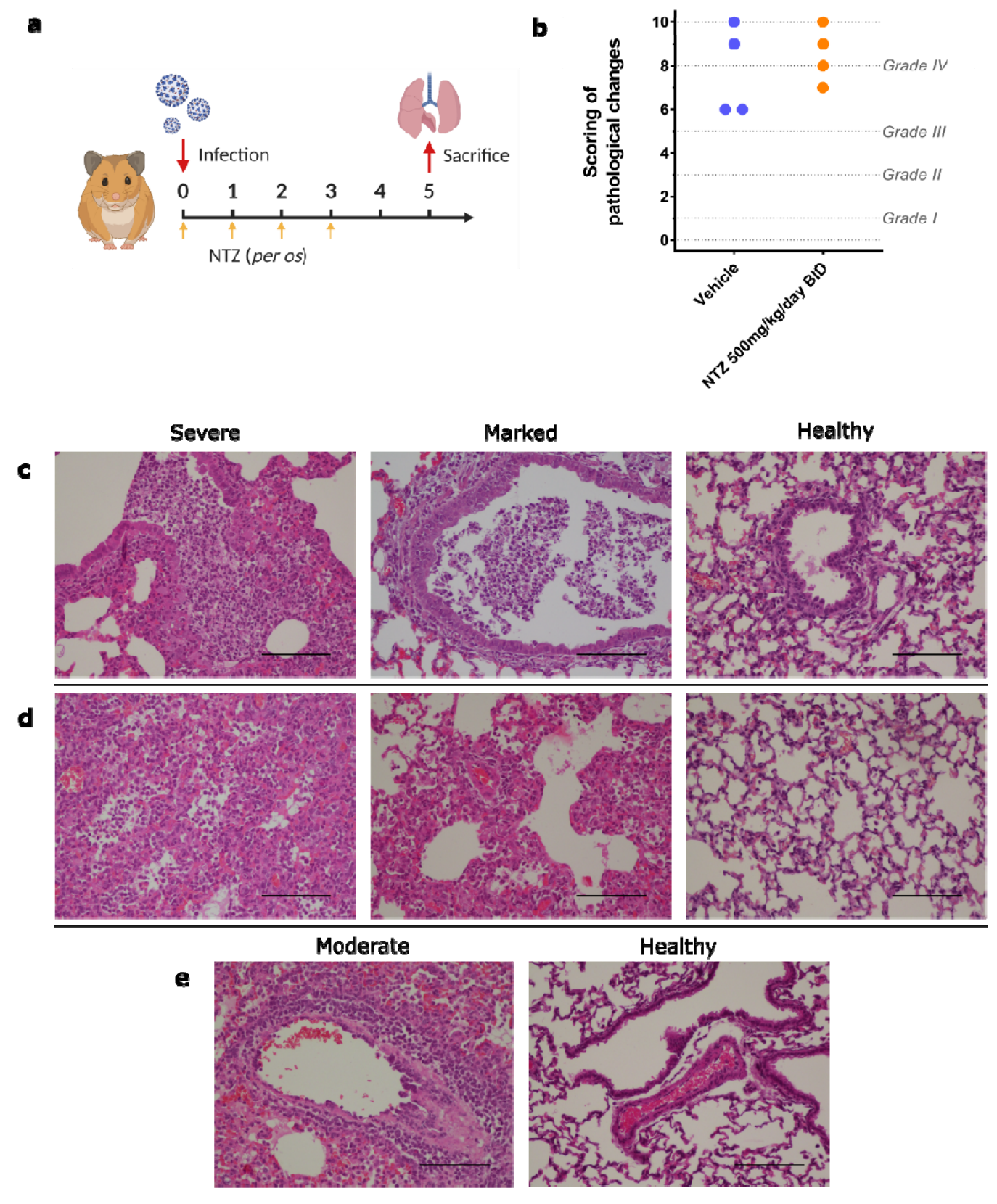

Figure 4: Lung histopathological changes.

176 Groups of 4 animals were intranasally infected with $10^{4} \mathrm{TCID}_{50}$ of virus and sacrificed at $5 \mathrm{dpi}$. Based on severity of 177 inflammation, alveolar hemorrhagic necrosis and vessel lesions, a cumulative score from 0 to 10 was calculated and 178 assigned to a grade of severity (I, II, III and IV). a Experimental timeline. b Scoring of pathological changes (Details in 179 Supplementary Data 3 and 4). c Representative images of bronchial inflammation (scale bar: 100 $\mu$ ): severe peribronchiolar inflammation and bronchiole filled with numerous neutrophilic, marked peribronchiolar inflammation and normal bronchi. 
d Representative images of alveolar inflammation (scale bar: $100 \mu$ ): severe infiltration of alveolar walls, alveoli filled with neutrophils/macrophages, marked infiltration of alveolar walls, some alveoli filled with neutrophils/macrophages and normal alveoli. e Representative images of vessel inflammation (scale bar: $100 \mu$ ): moderate accumulation of inflammatory cells in arteriolar walls and normal arteriole.

To investigate if the lack of efficacy seen in lungs was due to an inadequate drug diffusion, we assessed the exposure and the lung distribution of TIZ (the active circulating metabolite of NTZ). We used tissues from infected animals sacrificed at 3 dpi following multiple administration (animals from Figure 3); an additional group of uninfected animals treated with a single dose of $13.5 \mathrm{mg}$ was used as control. TIZ concentration in plasma and in lung was quantified at 1,2 and 4 hours post treatment for the single dose analysis (group of 3 animals) and at 12 hours after the last administration for the multiple dose analysis (group of 6 animals).

These animals exhibited low penetration rates of TIZ in lungs, resulting in lung/plasma ratio ranging from $2.2 \%$ to $4.8 \%$ after single-dose administration (Table 1 ). Lung concentrations of TIZ were below the TIZ EC 50 found in vitro with Vero E6 cells $(7.48 \mu \mathrm{M}$, i.e $1.98 \mu \mathrm{g} / \mathrm{mL})$, as well as effective NTZ concentrations ex vivo $(5 \mu \mathrm{M}$, i.e $1.54 \mu \mathrm{g} / \mathrm{mL})$, and were not quantifiable in a total of 5 out of 9 animals (one at 1 hour, two at 2 hours and two at 4 hours) (Table 1). After 3 days of multiple dose treatment, TIZ trough concentrations (12 hours after the last administration) in lungs were still below the in vitro $\mathrm{EC}_{50}$ and not quantifiable in a total of 8 out of 12 animals (four for each multiple dose concentration) (Table 1).

\begin{tabular}{|c|c|c|c|c|}
\hline & Time post-treatment & Plasma $\mu \mathrm{g} / \mathrm{mL}$ & Lung $\mu \mathrm{g} / \mathrm{g}$ & L/p ratio $(\%)$ \\
\hline \multirow{2}{*}{$\begin{array}{c}\text { Single Dose: } 13.5 \mathrm{mg} \\
\text { (control uninfected) }\end{array}$} & $\begin{array}{c}5 \text { hour } \\
(19.16 \pm 4.24\end{array}$ & $\begin{array}{c}0.16 ; 0.22 \S \\
(0.61 ; 0.84 \mu \mathrm{M} / \mathrm{g})\end{array}$ & $4.8 ; 2.2$ \\
\cline { 2 - 5 } & 2 hours & $\begin{array}{c}3.39 \pm 1.76 \\
12.8 \pm 6.62 \mu \mathrm{M}\end{array}$ & $\begin{array}{c}0.13 \ltimes \\
(0.50 \mu \mathrm{M} / \mathrm{g})\end{array}$ & 2.7 \\
\cline { 2 - 5 } & 4 hours & $\begin{array}{c}0.82 \pm 0.57 \\
(3.10 \pm 2.16 \mu \mathrm{M})\end{array}$ & $\begin{array}{c}0.06 \ltimes \\
(0.23 \mu \mathrm{M} / \mathrm{g})\end{array}$ & 4.2 \\
\hline Multiple Dose: $500 \mathrm{mg} / \mathrm{kg} /$ day BID (at 3 dpi) & 12 hours & $\begin{array}{c}0.94 \pm 1.07 \S \\
(3.54 \pm 4.21 \mu \mathrm{M})\end{array}$ & $\begin{array}{c}0.06 ; 0.06 \$ \\
(0.21 ; 0.21 \mu \mathrm{M} / \mathrm{g})\end{array}$ & $2.7 ; 32.8$ \\
\hline Multiple Dose: $750 \mathrm{mg} / \mathrm{kg} /$ day TID (at 3 dpi) & 12 hours & $\begin{array}{c}1.49 \pm 1.15 \\
(5.63 \pm 4.35 \mu \mathrm{M})\end{array}$ & $\begin{array}{c}0.07 ; 0.16 \$ \\
(0.28 ; 0.60 \mu \mathrm{M} / \mathrm{g})\end{array}$ & $2.9 ; 6.3$ \\
\hline
\end{tabular}

Table 1: Plasma and lung concentrations of TIZ after administration of a single dose or multiple dose of NTZ. Multiple Dose: PK realized after 3 days of nitazoxanide administered two or three times a day, at the end of the dosing interval (trough concentrations). Data represent mean \pm SD for plasma concentrations and individual values for lung concentrations and $L / p$ ratios. These data represent a summary of Supplementary Data 4 . Symbols $\S$, $x$ and $\$$ represent respectively 1, 2 and 4 values below the limit of quantification.

\section{$\underline{\text { NTZ efficacy evaluation following intranasal administration }}$}

To assess other administration routes for NTZ, we explored the antiviral efficacy of an intranasal NTZ emulsion (aqueous phase: sterile distilled water $94 \%$ and absolute ethanol $6 \%$; organic phase: NTZ 
$21320 \mathrm{mg} / \mathrm{mL}$ in cinnamaldehyde $75 \%$ and Kolliphore EL 25\%). Hamsters were intranasally infected with

$21410^{4} \mathrm{TCID}_{50}$ of SARS-CoV-2. A group of 6 hamsters received intranasally $2.8 \mathrm{mg} / \mathrm{kg} / \mathrm{day}$ TID of NTZ

215 (Figure 5a). An untreated group of 6 hamsters received the emulsion vehicle TID. All treatments were

216 started at the day of infection and ended at day 2 post infection. Viral replication was assessed in

217 lungs, plasma and nasal turbinates at $3 \mathrm{dpi}$.

218

219 NTZ intranasal treatment led to a significant increase of infectious titers in clarified lung 220 homogenates $(p=0.0003$ ) (Figure $5 b)$. No significant differences were observed when looking at viral 221 RNA yields in both clarified lung homogenates and plasma with both intranasal treatments $222(p \geq 0.4530)$ (Figure $5 c$ and $5 d$ ). In nasal turbinates, no significant differences of infectious titers were 223 observed between the groups $(p=0.6295)$ (Figure $5 e$ ). When looking at viral RNA yields, NTZ 224 treatment induced a significant reduction of viral RNA load in nasal turbinates ( $p=0.0037$ ) (Figure $5 f$ ). 225 Animals treated with NTZ intranasally from 1 to $3 \mathrm{dpi}$, showed clinical signs of illness/suffering, with 226 their mean normalized weight becoming significantly lower than that of untreated animals $(p=0.0314)$ (Figure $5 g)$. 


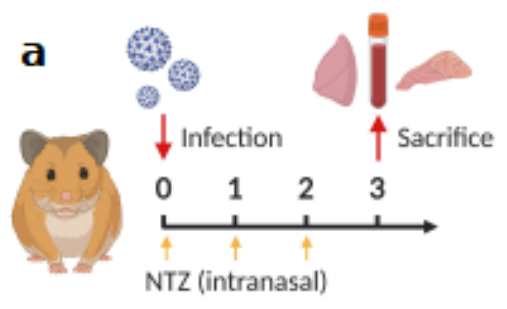

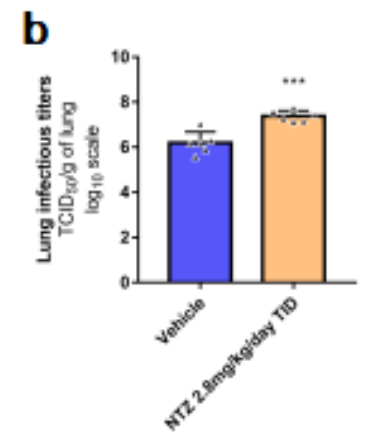

C

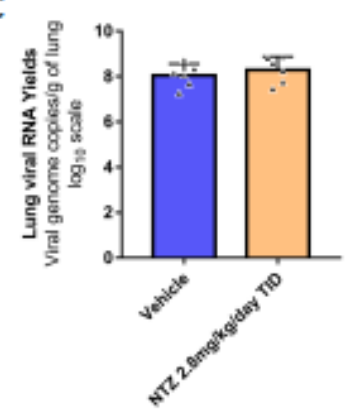

f

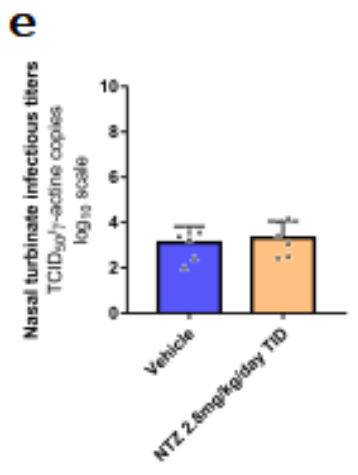

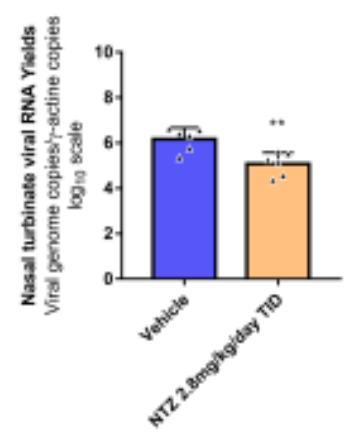

d

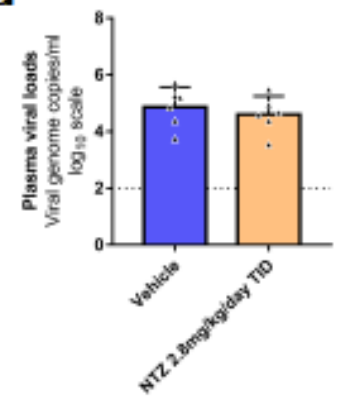

g

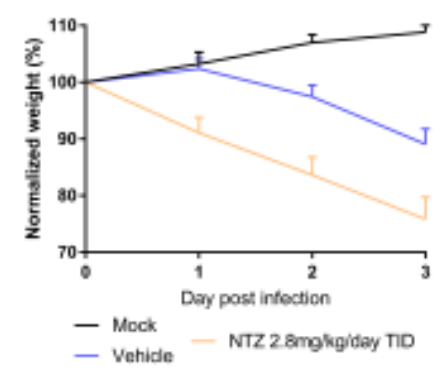

Figure 5: Antiviral activity of intranasal treatment of NTZ in a hamster model.

Groups of 6 hamsters were intranasally infected with $10^{4} \mathrm{TCID}_{50}$ of virus. a Experimental timeline. $\mathbf{b}$ Viral replication in lung based on infectious titers (measured using a $T_{C I D}$ assay) expressed in $T_{C I D} / g$ of lung ( $n=6$ animals/group). c Viral replication in lung based on viral RNA yields (measured using an RT-qPCR assay) expressed in viral genome copies/g of lung ( $n=6$ animals/group). d Plasma viral loads (measured using an RT-qPCR assay) are expressed in viral genome copies/mL of plasma (the dotted line indicates the detection threshold of the assay) ( $n=6$ animals/group). e Viral replication in nasal turbinates based on infectious titers (measured using a $T_{C I D}$ assay) expressed in $T C I D_{50} /$ copy of al-actine gene ( $n=6$ animals/group). $f$ Viral replication in nasal turbinates based on viral RNA yields (measured using an RT-qPCR assay) expressed in viral genome copies/copy of at-actine gene ( $n=6$ animals/group). g Clinical course of the disease ( $n=6$ animals/group). Normalized weight at day $n$ was calculated as follows: $\%$ of initial weight of the animal at day $n$. Data represent mean \pm SD (Details in Supplementary Data 1 ). ${ }^{* *}$ symbols indicate that the average value for the group is significantly lower than that of the untreated group with a p-value ranging between 0.001-0.01 (Details in Supplementary Data 1).

To confirm these results, the experiment was repeated independently. Overall, no significant differences in viral replication between treated and untreated hamsters were observed in either clarified lung homogenates, plasma or nasal turbinates (Supplementary Fig. 2). Once again, hamsters treated with NTZ intranasally from 1 to $3 \mathrm{dpi}$, showed clinical signs of illness/suffering, with their 
mean normalized weight becoming significantly lower than that of untreated animals

248 (Supplementary Fig. 2).

Similarly to the oral administration study, and to investigate a potential issue regarding drug distribution to the compartment of choice, we also assessed the plasma, lung and nasal turbinates concentrations of TIZ following intranasal NTZ administration in infected animals treated by multiple doses, 12 hours after the last administration (group of 6 hamsters from figure 5). Overall, TIZ was detectable in only 2 out of 6 animals (one in plasma and lung; one in lung and nasal turbinates) (Supplementary Table 1) but TIZ concentrations were below the $\mathrm{EC}_{50}$ found in vitro and the active concentration ex vivo.

\section{$\underline{\text { Pharmacokinetic modelling }}$}

We characterized the pharmacokinetic profile of TIZ in hamster after administration of the same NTZ suspension or TIZ formulated in 10\% [Tween 80, 80\% EtOH (70:30 v/v)] and 90\% distilled water, homogenous opaque suspension. Groups of 3 hamsters received an oral single dose of $485 \mathrm{mg} / \mathrm{kg}$, $98.1 \mathrm{mg} / \mathrm{kg}$ or $25.5 \mathrm{mg} / \mathrm{kg}$ of NTZ or $96.4 \mathrm{mg} / \mathrm{kg}$ of TIZ. The corresponding concentration-time curves for NTZ administration only are presented in Supplementary Fig. 3. Notably, similar concentrationtime curves of TIZ were observed following oral administration of $98.1 \mathrm{NTZ}$ or $96.4 \mathrm{mg} / \mathrm{kg} \mathrm{of} \mathrm{TIZ}$, suggesting full in-vivo conversion of NTZ into TIZ (Supplementary Fig. 3). The observed TIZ plasma concentration-time data in hamster, following oral administration of NTZ and TIZ, were characterized using nonlinear mixed-effects modelling. The data were best described by a two-compartment disposition model with first-order absorption. The population pharmacokinetic parameters estimates from the final model are presented in Supplementary Table 2. Time to maximum concentration $\left(T_{\max }\right)$ and terminal elimination half-life $\left(\mathrm{t}_{1 / 2}\right)$ were estimated to $0.276 \mathrm{~h}$ and $0.80 \mathrm{~h}$, respectively. Graphically, the model showed good adequacy between predicted concentrations and observed concentrations (Supplementary Fig. 4) the population pharmacokinetic model are presented in Table 2.

\begin{tabular}{|c|c|c|}
\hline NTZ dose $(\mathrm{mg} / \mathrm{kg})$ & $\mathrm{C}_{\max }(\mu \mathrm{g} / \mathrm{ml})$ & $\mathrm{AUC}_{0-24 \mathrm{~h}}(\mu \mathrm{g} \cdot \mathrm{h} / \mathrm{ml})$ \\
\hline 25.0 & 3.14 & 4.18 \\
\hline 50.0 & 6.27 & 8.36 \\
\hline 100 & 12.5 & 16.7 \\
\hline 125 & 15.7 & 20.9 \\
\hline 250 & 31.4 & 41.8 \\
\hline 500 & 62.7 & 83.6 \\
\hline
\end{tabular}


Table 2: Simulated pharmacokinetic parameters derived from nonlinear mixed-effect modelling using population mean values and median body weight of $0.126 \mathrm{~kg}$. $\mathrm{C}_{\text {max }}$ : maximum plasma drug concentration; $\mathrm{AUC}_{0-24 \mathrm{~h}}$ : area under the concentration-time curve from time 0 to $24 \mathrm{~h}$.

We then compared the pharmacokinetic profile of $\mathrm{TIZ}$ in hamster to that in human. The pharmacokinetic model developed to describe the TIZ concentration-time data in hamster was used to simulate plasma drug exposures in hamster using different dose regimens. From these

A

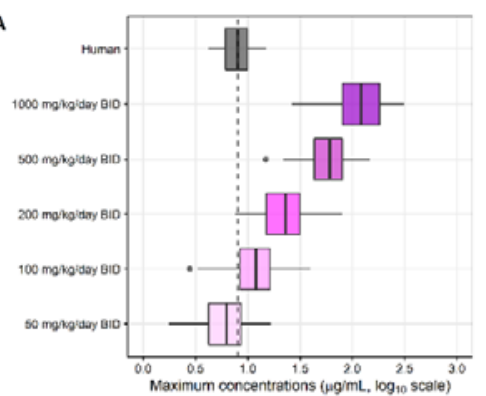

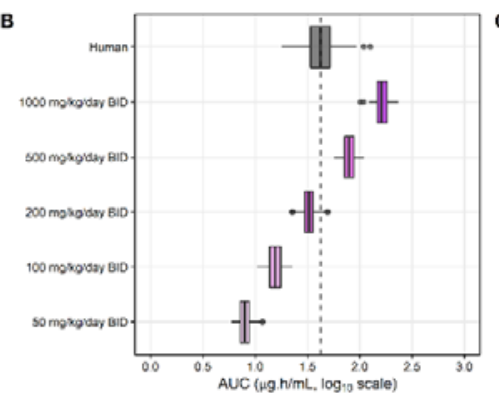

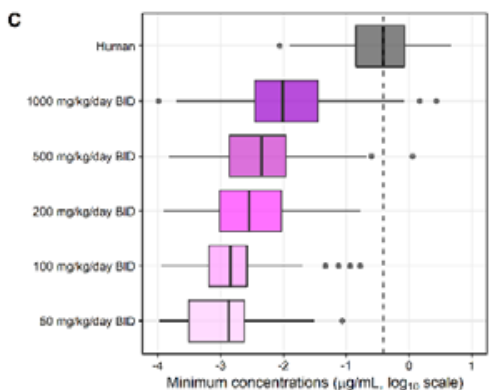

Figure 6: Simulated pharmacokinetic parameters of TIZ in human and hamster at steady state.

Predicted steady-state pharmacokinetic parameters of TIZ, i.e. $C_{\max }(A)$, AUC (B) and $C_{\min }(C)$, in human associated with receiving $1000 \mathrm{mg} /$ day BID of NTZ (grey box) were compared with pharmacokinetic parameters of hamster receiving 50 , $100,200,500$ and $1000 \mathrm{mg} / \mathrm{kg} /$ day BID of NTZ (colored boxes). Boxes and whiskers represent the median with inter-quantile range and the $95 \%$ prediction intervals, respectively. 


\section{Discussion}

302

303

304

305

306

307

308

309

310

311

312

313

314

315

316

317

318

319

320

321

322

323

324

325

326

327

328

329

330

331

332

Nitazoxanide was among the very first molecules studied at the beginning of the COVID-19 pandemic, revealing an in vitro antiviral efficacy against SARS-CoV-2 (13-19). Our study confirms these results, as we found that NTZ possesses $\mathrm{EC}_{50}$ under $5 \mu \mathrm{M}$ in two different cell lines. In addition, we demonstrated that NTZ was active in bronchial human airway epithelia, which largely mimic the structural, functional, and innate immune features of the human respiratory epithelium, albeit at lower potency as compared to Rem desivir, the positive control in this assay (26).

It is well documented that, in vivo, NTZ is rapidly deacetylated to its active metabolite, TIZ (29). However, only one non-peer-reviewed source reported the activity of TIZ against SARS-CoV-2 (https://opendata.ncats.nih.gov/covid19/databrowser). Here, we demonstrated that this metabolite is indeed active against SARS-CoV-2 in vitro with an $\mathrm{EC}_{50}$ of $7.48 \mu \mathrm{M}$, reinforcing the potential use of NTZ in COVID-19 management.

Although mainly considered as an antiprotozoal agent, NTZ, and its active circulating TIZ metabolite, were identified as in vitro broad-spectrum antiviral compounds, since they both inhibit the replication of a wide range of RNA and DNA viruses in cell culture $(6,8)$. Their antiviral mechanism has not been clearly elucidated. However, it seems that interaction with numerous targets implicated in viral pathogenesis, depending on the virus, is involved (immunomodulatory effects and direct drug action) (8). Notably, post-entry inhibition by upregulation of cell's innate antiviral response, observed against hepatitis $C$ virus on cell culture (30), may be one of the efficient antiviral pathways involved in SARS-CoV-2 inhibition. Recently, TMEM16 inhibitors, such as niclosamide and NT, have been reported to protect against cell fusion induced by SARS-CoV-2 spike protein in cell culture (31). This syncytia inhibition could be one of the modes of action observed in vitro and ex vivo for NTZ antiviral activity against SARS-CoV-2.

Although NTZ has had only incomplete preclinical characterization, numerous clinical trials using the molecule are underway around the world. We felt that the generation of robust preclinical data was relevant to document the suitability of NTZ for clinical use in the treatment of COVID patients.

Despite promising in vitro results and new hypotheses on its antiviral mechanism, NTZ failed to reduce the severity of SARS-CoV-2 infection in vivo in the Syrian hamster model. No significant improvement in terms of clinical course of the disease, viral replication (based on infectious titers or viral RNA yields) and/or histopathological damages in lungs was observed when using two different dosing regimens of NTZ. These findings could be explained by the insufficient pulmonary diffusion of 
$333 \mathrm{TIZ}$, since peak concentrations in lungs (1 hour post-treatment) never exceeded its in vitro or ex vivo

$334 E C_{50}$. This insufficient pulmonary exposure was confirmed by the low accumulation of TIZ over time in

335 the lungs as trough concentrations after 3 days of multiple doses of NTZ were similar to those found

3364 hours post-treatment in the single dose model. This result is in accordance with a previous clinical

337 trial assessing the safety, bactericidal activity, and pharmacokinetics of NTZ in adults with pulmonary

338 tuberculosis, where sputum concentration of NTZ was low, suggesting that it did not penetrate

339 pulmonary lesions to a sufficient degree (32). This can be explained in part by the physico-chemical

340 and pharmacokinetic characteristics of the product, which do not facilitate tissue diffusion. In

341 addition to being a moderately lipophilic molecule, TIZ is highly bound to plasma proteins (99\%).

342 Therefore, the use of NTZ as a systemic treatment might be challenging.

343 The PK modeling and simulations provided further insights for the lack of NTZ efficacy in the in vivo

344 hamster model of SARS-CoV-2 infection. Simulations showed that the dose of $500 \mathrm{mg} / \mathrm{kg} / \mathrm{day}$ BID

345 (found ineffective in our study) was sufficient to achieve $C_{\max }$ and AUC above those observed in

346 humans at the usual dose of $1000 \mathrm{mg} / \mathrm{kg} /$ day, but not sufficient to reach trough concentrations $\left(C_{\min }\right)$

347 observed in humans at this same dose. Furthermore, human $C_{\min }$ was never reached even with the

348 highest simulated dose $(1000 \mathrm{mg} / \mathrm{kg} /$ day BID). This prediction was confirmed in our in vivo study in

349 which we did not observe efficacy at the highest dose (i.e. $750 \mathrm{mg} / \mathrm{kg} /$ day TID). The latter

350 observations show a difference in the clearance of NTZ between humans and hamsters, of which the

$351 \quad C_{\min }$ can be considered a reflection, with a more rapid elimination in hamsters. Although differences

352 in pharmacokinetic profiles between humans and hamsters are known and widely documented,

353 these findings suggest that at the usual dose of $1000 \mathrm{mg} / \mathrm{kg} /$ day in humans, NTZ will have no effect on SARS-CoV-2 replication.

To potentially enhance the pulmonary diffusion and explore the possible antiviral activity of TIZ within the upper respiratory tract, hamsters were treated with an intranasal NTZ emulsion formulation. This alternative route of administration proved ineffective in our model, as no significant improvement in any of the disease endpoints analysed was observed. As observed after oral administration, TIZ trough concentration measured in lungs after 3 days of intranasal NTZ administration was very low, which may also partly explain the lack of antiviral efficacy ; in all samples tested, including nasal turbinates, TIZ concentration was found to be well below the in vitro and ex vivo $\mathrm{EC}_{50}$. This lack of $\mathrm{TIZ}$ accumulation in the upper respiratory tract should be interpreted with caution as no active intranasal deliverable compounds was available as a positive control in our study. 
367 Overall, based on the pharmacokinetic data collected in this pre-clinical study, the use of NTZ as an 368 antiviral against SARS-CoV-2, does not seem appropriate at the current standard formulation and 369 dosage. Our results suggest that the low pulmonary bioavailability of NTZ remains the major 370 challenge that needs to be addressed in order to properly evaluate the potential antiviral effect of 371 NTZ in an animal model or in human.

372 Clinical trials with NTZ are currently ongoing and their outcome will be very useful for back373 translation purposes. As an example, if preliminary data of a recent trial may suggest that NTZ could 374 have some beneficial impact in preventing worsening of the disease and need for hospitalization, 375 qualitative and quantitative tests to detect SARS-CoV-2 were not significantly different between the 376 treatment arms (33). These observations corroborate our results and demonstrate that it will be 377 essential to increase the pulmonary bioavailability of NTZ in order to conclude a direct antiviral 378 impact.

380 In conclusion, optimization of the NTZ formulation may allow reconsideration of the potential use of 381 the drug for the treatment of SARS-CoV-2 infection. In a previous pharmacokinetic study of NTZ in 382 mice, optimal concentrations of TIZ were obtained in the lungs when the molecule was entrapped in 383 inhalable particles (34). This type of formulation combined with aerosol administration could potentially lead to an effective concentration of NTZ in the animal's lungs and deserves further investigation. 


\section{Methods}

\section{Cells and human airway epithelia}

389 VeroE6 cells (ATCC CRL-1586) and Caco-2 cells (ATCC HTB-37) were cultivated under $5 \% \mathrm{CO}_{2}$ and at $39037.5^{\circ} \mathrm{C}$ in minimal essential medium (MEM) supplemented with $7.5 \%$ heat-inactivated fetal bovine 391 serum (FBS), 1\% non-essential amino acids and 1\% Penicillin/Streptomycin (all from Life 392 Technologies).

393 Mucilair $^{T M}$ human airway epithelia (HAE), reconstituted from primary cells of bronchial biopsies of a 394 56-year-old donor Caucasian female with no reported pathologies, was maintained in air liquid 395 interface with specific media (all from Epithelix SARL, Geneva, Switzerland, with informed consent).

397 Virus

398 SARS-CoV-2 strain BavPat1 was provided by Pr.Christian Drosten (Berlin, Germany) through European 399 Virus Archive GLOBAL (https://www.european-virus-archive.com/). Inoculation with this strain at a $400 \mathrm{MOI}$ of 0.001 , of a $25 \mathrm{~cm}^{2}$ culture flask of confluent VeroE6 cells with MEM medium supplemented 401 with 2.5\% FBS, allowed us to prepare virus working stocks. Each $24 \mathrm{~h}$ the cell supernatant medium 402 was replaced in order to be harvested at the peak of infection. It was supplemented with $25 \mathrm{mM}$ 403 HEPES (Sigma-Aldrich), aliquoted and stored at $-80^{\circ} \mathrm{C}$. Experiments with infectious virus were 404 performed in a biosafety level 3 laboratory. 


\section{In vitro determination of $\mathrm{EC}_{50}$ and $\mathrm{CC}_{50}$}

407 One day prior to infection, 96-well culture plates were seeded with $5 \times 10^{4}$ VeroE6 or Caco- 2 cells in $408100 \mu \mathrm{L}$ assay medium per well (containing 2.5\% FCS). The next day, eight 2 -fold serial dilutions of 409 compounds (from $20 \mu \mathrm{M}$ to $0.16 \mu \mathrm{M}$ for NTZ (BLDpharm) and from $100 \mu \mathrm{M}$ to $0.78 \mu \mathrm{M}$ for TIZ 410 (MedChemExpress)) in triplicate were added to the cells $(25 \mu \mathrm{L} /$ well, in assay medium). For the 411 determination of the $50 \%$ and $90 \%$ effective concentrations $\left(\mathrm{EC}_{50}, \mathrm{EC}_{90}\right.$; compound concentration 412 required to inhibit by $50 \%$ or $90 \%$ viral RNA replication), four "virus control" wells were 413 supplemented with $25 \mu \mathrm{L}$ of assay medium without any compounds. After $15 \mathrm{~min}$, a preset amount of 414 virus diluted in $25 \mu \mathrm{L}$ of assay medium was added to the wells. This quantity of virus was calibrated so 415 that the viral replication was still in the exponential growth phase for the readout, as previously 416 described $(24,25,35)$. Four "cell control" wells were supplemented with $50 \mu \mathrm{L}$ of assay medium 417 without any compounds or virus. On each culture plate, a positive control compound (Remdesivir, 418 BLDpharm) was added in duplicate with eight 2-fold serial dilutions $(0.16 \mu \mathrm{M}$ to $20 \mu \mathrm{M})$. Plates were 419 incubated for 2 days at $37^{\circ} \mathrm{C}$ prior to quantification of the viral genome by real-time RT-PCR as 420 described below. For the determination of the $50 \%$ cytotoxic concentrations $\left(\mathrm{CC}_{50}\right.$; compound 421 concentration required to reduce by $50 \%$ cell viability), the same culture conditions were used, 422 without addition of the virus, and cell viability was measured using CellTiter Blue ${ }^{\circledR}$ (Promega) 423 following manufacturer's instructions. $\mathrm{EC}_{50}, \mathrm{EC}_{90}$ and $\mathrm{CC}_{50}$ were determined using logarithmic 424 interpolation as previously described (25). The selectivity index of the compounds was calculated as 425 the ratio of the $\mathrm{CC}_{50}$ over the $\mathrm{EC}_{50}$.

\section{Ex vivo determination of antiviral activity}

428 After being washed with pre-warmed OptiMEM medium (Life technologies), human airway epithelia 429 were infected with SARS-CoV-2 at the apical side using a $\mathrm{MOI}$ of 0.1 , as previously described 430 (Pizzorno et al., 2020). Cells were cultivated in a basolateral medium that contained NTZ or 431 remdesivir (positive control) at different concentrations or with no drug (virus control). Each day, 432 medium was renewed and samples containing viral RNA were collected by washing the apical side 433 with $200 \mu \mathrm{L}$ of pre-warmed OptiMEM medium. Four day after the infection, total intracellular RNA of 434 each well was extracted using the RNeasy $96 \mathrm{HT}$ kit (Qiagen) following manufacturer's instructions. 435 Viral RNA was quantified by RT-qPCR and infectious titers were determined in daily samples by $436 \mathrm{TCID}_{50}$, both described below. Ex vivo experiments were approved by ethical committee and were 437 conducted according to the declaration of Helsinki on biomedical research (Hong Kong amendment, 438 1989). 


\section{$440 \quad$ In vivo experiments}

\section{Approval and authorization}

442 In vivo experiments were approved by the local ethical committee (C2EA-14) and the French 443 'Ministère de l'Enseignement Supérieur, de la Recherche et de I'Innovation' (APAFIS\#23975). Animal 444 experimentations were performed in accordance with the French national guidelines and the 445 European legislation covering the use of animals for scientific purposes.

\section{$446 \quad$ Animal handling}

447 Three-week-old female Syrian hamsters were provided by Janvier Labs. Animals were maintained in 448 ISOcage P - Bioexclusion System (Techniplast) with unlimited access to water/food and 14h/10h 449 light/dark cycle. Animals were weighed and monitored daily for the duration of the study to detect 450 the appearance of any clinical signs of illness/suffering. General anesthesia was obtained with 451 isoflurane (Isoflurin ${ }^{\circledast}$, Axience). Euthanasia, which was also realized under general anesthesia, was 452 performed by cervical dislocation.

\section{Hamster Infection}

454 Four-week-old anesthetized animals were intranasally infected with $50 \mu \mathrm{L}$ containing $10^{4} \mathrm{TCID}_{50}$ of 455 virus in $0.9 \%$ sodium chloride solution. The mock-infected group was intranasally inoculated with $45650 \mu \mathrm{L}$ of $0.9 \%$ sodium chloride solution.

457 Drug preparation and administration

458 Hamsters were orally treated with either a NTZ solution at $10 \mathrm{mg} / \mathrm{mL}$, suspension at $27 \mathrm{mg} / \mathrm{mL}$ or 459 emulsion at $2.5 \mathrm{mg} / \mathrm{mL}$, prepared from NTZ powder (BLD Pharm). The solution was prepared with $460 \quad 0.5 \%$ of hydroxypropyl methylcellulose and $0.1 \%$ of tween 80 . For the suspension NTZ was dissolved 461 in a vehicle composed of $90 \%(v / v)$ sterile distilled water, $7 \%(v / v)$ of tween 80 and $3 \%(v / v)$ 462 ethanol $80 \%$. The emulsion (aqueous/organic phase ratio of $80 / 20$ ) for intranasal instillation was 463 prepared with an aqueous phase (sterile distilled water $94 \%$ and absolute ethanol 6\%) added 464 gradually to an organic phase (NTZ $20 \mathrm{mg} / \mathrm{mL}$ in cinnamaldehyde $75 \%$ and Kolliphore EL $25 \%$ ) under constant stirring. A solution of favipiravir, reconstituted from anhydrous favipiravir (Toyama-

466 Chemical) with $0.9 \%$ sodium chloride solution, was used for intra-peritoneally and intranasally 467 treatment. Control group were orally or intranasally inoculated with a $0.9 \%$ sodium chloride solution. 468 Tissue collection

469 Lungs, nasal turbinates and blood were collected immediately after euthanasia. The left pulmonary 470 lobe was first rinsed in $10 \mathrm{~mL}$ of $0.9 \%$ sodium chloride solution, blotted with filter paper and weighed. 471 Nasal turbinates and pulmonary lobes were transferred to a $2 \mathrm{~mL}$ tube containing respectively $500 \mu \mathrm{L}$ 472 or $1 \mathrm{~mL}$ of $0.9 \%$ sodium chloride solution and $1 \mathrm{~mm}$ or $3 \mathrm{~mm}$ glass beads. They were crushed using a 
473 Tissue Lyser machine (Retsch MM400) for $5 \mathrm{~min}$ at 30 cycles/s and then centrifuged $10 \mathrm{~min}$ at $47416,200 \mathrm{~g}$. Crushed nasal tubinates were stored at $-80^{\circ} \mathrm{C}$ while lung supernatant media were 475 transferred to a $1.5 \mathrm{~mL}$ tube, for another centrifugation during $10 \mathrm{~min}$ at $16,200 \mathrm{~g}$ prior being stored 476 at $-80^{\circ} \mathrm{C}$. One milliliter of blood was harvested in a $2 \mathrm{~mL}$ tube containing $100 \mu \mathrm{L}$ of $0.5 \mathrm{M}$ EDTA (Life 477 Technologies). Blood was centrifuged for $10 \mathrm{~min}$ at $16,200 \mathrm{~g}$ and stored at $-80^{\circ} \mathrm{C}$.

\section{Quantitative real-time RT-PCR (RT-qPCR) assays}

480 All experiments were conducted in a molecular biology laboratory that is specifically devoted to 481 molecular clinical diagnosis and which includes separate laboratories dedicated to each step of the 482 procedure. Prior to PCR amplification, RNA extraction was carried out using the QIAamp 96 DNA kit 483 and the Qiacube HT kit and the Qiacube HT (both from Qiagen) following the manufacturer's 484 instructions. Shortly, $100 \mu \mathrm{l}$ of tissue clarified homogenates, spiked with $10 \mu \mathrm{L}$ of internal control 485 (bacteriophage MS2), or viral supernatant were transferred into an S-block containing the 486 recommended volumes of $\mathrm{VXL}$, proteinase $\mathrm{K}$ and RNA carrier.

487 RT-qPCR (SARS-CoV-2 and MS2 viral genome detection) were performed with the GoTaq 1-step qRtPCR kit (Promega) using $3.8 \mu \mathrm{L}$ of extracted RNA and $6.2 \mu \mathrm{L}$ of RT-qPCR mix that contains $250 \mathrm{nM}$ of each primer and $75 \mathrm{nM}$ of probe. Primers and probes sequences used are described in Supplementary Table 3. Quantification was provided by four 2 log serial dilutions of an appropriate T7-generated synthetic RNA standard of known quantities $\left(10^{2}\right.$ to $10^{8}$ copies/reaction). Amplification was performed with the QuantStudio 12K Flex Real-Time PCR System (Applied Biosystems) using standard fast cycling parameters: $10 \mathrm{~min}$ at $50^{\circ} \mathrm{C}, 2 \mathrm{~min}$ at $95^{\circ} \mathrm{C}$, and 40 amplification cycles $\left(95^{\circ} \mathrm{C}\right.$ for $3 \mathrm{sec}$ followed by $30 \mathrm{sec}$ at $60^{\circ} \mathrm{C}$ ). qPCR (?]-actine gene detection) was performed under the same condition as RT-qPCR with the following modifications: we used the Express one step qPCR Universal kit (ThermoFisher Scientific) and the $50^{\circ} \mathrm{C}$ step of the amplification cycle was removed. Results were analyzed using QuantStudio 12K Flex Applied Biosystems software v1.2.3.

498

499 Tissue-culture infectious dose $50\left(\operatorname{TCID}_{50}\right)$ assay

500 To determine infectious titers, 96-well culture plates containing confluent VeroE6 cells were 501 inoculated with $150 \mu \mathrm{L}$ per well of serial dilutions of each sample (ten-fold or four-fold dilutions when 502 analyzing cell supernatant media or lung clarified homogenates respectively). Each dilution was 503 performed in sextuplicate. After 5 days of incubation, plates were read for the absence or presence 504 of cytopathic effect in each well. Infectious titers were estimated using the method characterized by 505 Reed \& Muench (36). 
507 Nitazoxanide quantification in plasma and tissues

508 Quantification of TIZ in plasma and lung tissues was performed by high-performance liquid 509 chromatography with UV detection method (Alliance 2695, Waters, USA) with a lower limit of 510 quantification of $0.01 \mu \mathrm{g} / \mathrm{mL}$. The mobile phase consisted of $0.1 \% \mathrm{FA}$ in water and $0.1 \%$ of FA in ACN $511(65: 35, v / v)$. The chromatographic separation was achieved using an isocratic mode with an Xbridge 512 BEH C18 $2.5 \mu \mathrm{m} 4.6 \times 100 \mathrm{~mm}$ column. Peak area was quantified at 340nm using the Waters 2489 513 detector. TIZ was extracted by a simple protein precipitation method, using acetonitrile for plasma 514 and ice-cold acetonitrile for clarified lung homogenates. Briefly, $200 \mu \mathrm{L}$ of samples matrix was added 515 to $1000 \mu \mathrm{L}$ of acetonitrile solution containing the internal standard (thiopental), then vortexed for $5162 \mathrm{~min}$ followed by centrifugation for $10 \mathrm{~min}$ at $4^{\circ} \mathrm{C}$. The supernatant medium was evaporated under 517 vacuum, then transferred to a $1.5 \mathrm{~mL}$ Eppendorf tube. The dried residue was reconstituted with $100 \mu \mathrm{l}$ 518 of $\mathrm{ACN}$ :water (50:50), vortexed for 30 seconds and centrifuged again for $10 \mathrm{~min}$ at $4^{\circ} \mathrm{C}$. The 519 supernatant was transferred to an autosampler and $50 \mu \mathrm{L}$ was injected.

\section{Histology}

522 Animal handling, hamster infections, NTZ preparation and oral administrations were performed as 523 described above. The anatomo-histological study was implemented as previously described (22). 524 Briefly, lungs were collected after intratracheal instillation of $4 \%(w / v)$ formaldehyde solution, and 525 then fixed $72 \mathrm{~h}$ at room temperature with a $4 \%(\mathrm{w} / \mathrm{v})$ formaldehyde solution before being embedded 526 in paraffin. Tissue sections of $3.5 \mu \mathrm{m}$ were stained with hematoxylin-eosin (H\&E) and blindly analyzed 527 by a certified veterinary pathologist. Microscopic examination was done using a Nikon Eclipse E400 microscope. Different anatomic compartments were examined (1) for bronchial and alveolar walls, a score of 0 to 4 was assigned based on severity of inflammation; (2) regarding alveoli, a score of 0 to 2 was assigned based on presence and severity of hemorrhagic necrosis; (3) regarding vessel changes (leucocytic accumulation in vascular wall or in endothelial compartment), absence or presence was scored 0 or 1 respectively. A cumulative score was then calculated and assigned to a grade of severity (see Supplementary Table 4).

\section{Pharmacokinetic modelling and simulation}

536 NTZ is rapidly and completely hydrolyzed into its active metabolite $\operatorname{TIZ}(29,37)$. Therefore, the 537 pharmacokinetic properties of NTZ were described using measured TIZ concentration in plasma.

538 At each time point, approximate $80 \mu \mathrm{l}$ of blood were collected from the submandibular vein or the 539 saphenous vein of hamsters. All samples were transferred into commercial K2-EDTA tubes, placed on 
540 ice until processed for plasma extraction by centrifugation and stored at $-70^{\circ} \mathrm{C}$ before analysis. A LC-

541 MS/MS-Al Triple Quad 5500 was used to determine TIZ concentrations. The mobile phase was a 542 gradient of $0.1 \%$ formic acid (FA) in water and $0.1 \%$ of FA in acetonitrile (ACN), the column was an 543 ACQUITY UPLC HSS T3 $1.8 \mu \mathrm{m} 2.1 \times 50 \mathrm{~mm}$. For mass spectrometry a positive electrospray ionization 544 was used, and a selected reaction monitoring was set to select TIZ: $[M+H]+m / z: 266.0 / 121.2$ and 545 dexamethasone: $[\mathrm{M}+\mathrm{H}]+\mathrm{m} / \mathrm{z}: 393.0$ / 373.1 as internal standard.

546 Pharmacokinetic profiles of TIZ in hamster were analyzed using a nonlinear mixed-effects modelling 547 approach. The population pharmacokinetics analysis was performed using NONMEM ${ }^{\circledR}$ version 7.4. 548 The final pharmacokinetic model was established by evaluating one-, two-, and three-compartment 549 disposition models, as well as several different absorption models (i.e. first-order absorption, first550 order absorption with lag time, and transit absorption models). The inter-individual variabilities of 551 pharmacokinetic parameters were implemented as a log-normal distribution and the residual 552 unexplained variability was modelled as an exponential error. Different doses of NTZ (i.e., 50, 100, 553200,500 and $1000 \mathrm{mg} / \mathrm{kg} /$ day BID) were used to simulate TIZ exposures in hamsters $(n=100)$ in order 554 to compare to the simulated human exposure.

To simulate human PK profiles, a one-compartment model was used with pharmacokinetic parameters from an established PBPK model (28), developed to describe pharmacokinetic data of TIZ plasma concentrations in healthy individuals receiving single doses of 500-4000mg NTZ with/without food, presenting an apparent clearance of $19.34 \mathrm{~L} / \mathrm{h}$ and a volume of distribution of $38.68 \mathrm{~L}$. The absorption was described with a first-order process and the rate constant $\left(k_{a}\right)$ of $0.45 h^{-1}$ was assumed in order to generate the mean concentration-time profile with a $T_{\max }$ at approximately 2 hours, as reported in healthy volunteers (38). This model was used to simulate drug exposure at individuals. A total of 10 doses ( 5 days) were used for estimating the convergence rate to steady state.

All exposure simulations were performed in $\mathrm{R}$ version 4.0.4 using the mlxR package (39).

\section{Graphical representations and statistical analysis}

568 Graphical representations and statistical analyses (two-sided tests when relevant) were performed 569 with Graphpad Prism 7 (Graphpad software). P-values lower than 0.05 were considered statistically 570 significant. Statistical details for each experiment are described in the figure legends and in corresponding Supplementary Data. Experimental timelines were created on biorender.com. 


\section{Acknowledgments}

574 We thank Laurence Thirion (UVE; Marseille) for providing RT-qPCR systems. We thank Camille Placidi

575 (UVE; Marseille) for her technical contribution. We thank Pr Drosten and Pr Drexler for providing the

576 SARS-CoV-2 strain through the European Research infrastructure EVA GLOBAL. We thank Toyama-

577 Chemical Favipiravir for kindly providing the favipiravir. This work was supported by the Fondation de

578 France "call FLASH COVID-19", project TAMAC, by "Institut national de la santé et de la recherche

579 médicale" through the REACTing (REsearch and ACTion targeting emerging infectious diseases), by

580 REACTING/ANRS MIE under the agreement No. 21180 ('Activité des molécules antivirales dans le

581 modèle hamster'), by European Virus Archive Global (EVA 213 GLOBAL) funded by the European

582 Union's Horizon 2020 research and innovation program under grant agreement No. 871029 and

583 DNDi under support by the Wellcome Trust Grant ref: 222489/Z/21/Z through the COVID-19

584 Therapeutics Accelerator". Part of this work was supported by the Wellcome Trust [220211]. Part of

585 the work was done on the Aix Marseille University antivirals platform "AD2P". For the purpose of

586 open access, the author has applied a CC BY public copyright licence to any Author Accepted

587 Manuscript version arising from this submission.

588

589 Materials \& Correspondence

590 Correspondence to Jean-Sélim Driouich. 
bioRxiv preprint doi: https://doi.org/10.1101/2021.12.17.473113; this version posted December 20, 2021. The copyright holder for this preprint (which was not certified by peer review) is the author/funder, who has granted bioRxiv a license to display the preprint in perpetuity. It is made available under aCC-BY 4.0 International license.

\section{Supplementary Data}

592
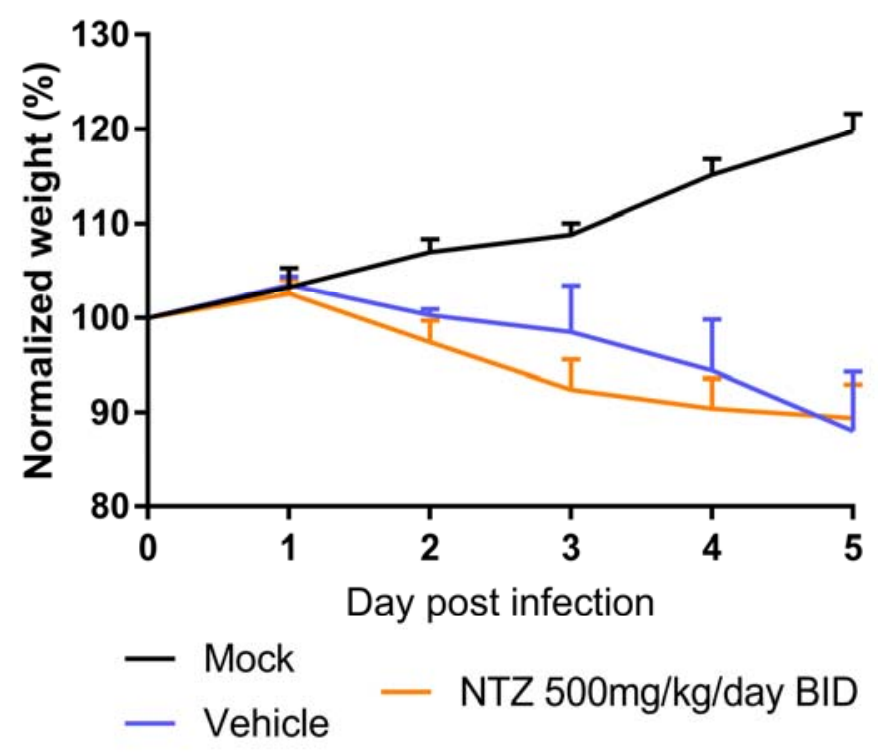

593

Supplementary Fig. 1: Clinical course of the disease ( $n=4$ animals/group). Normalized weight at day $n$ was calculated as follows: \% of initial weight of the animal at day $n$. Data represent mean \pm SD (Details in Supplementary Data 3). 
bioRxiv preprint doi: https://doi.org/10.1101/2021.12.17.473113; this version posted December 20, 2021. The copyright holder for this preprint (which was not certified by peer review) is the author/funder, who has granted bioRxiv a license to display the preprint in perpetuity. It is made available under aCC-BY 4.0 International license.

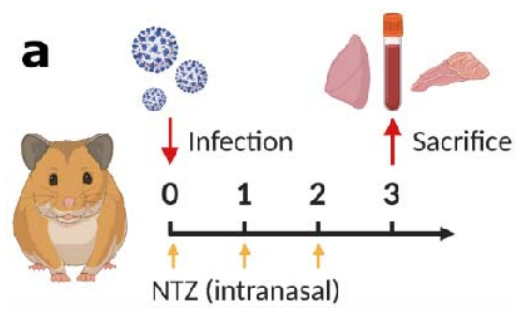

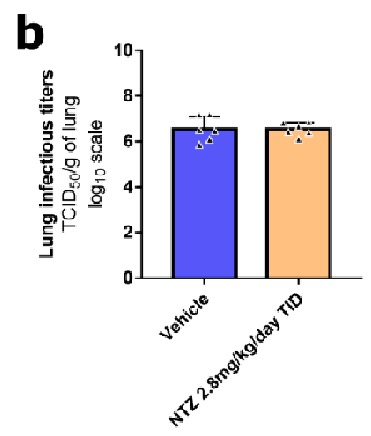

C
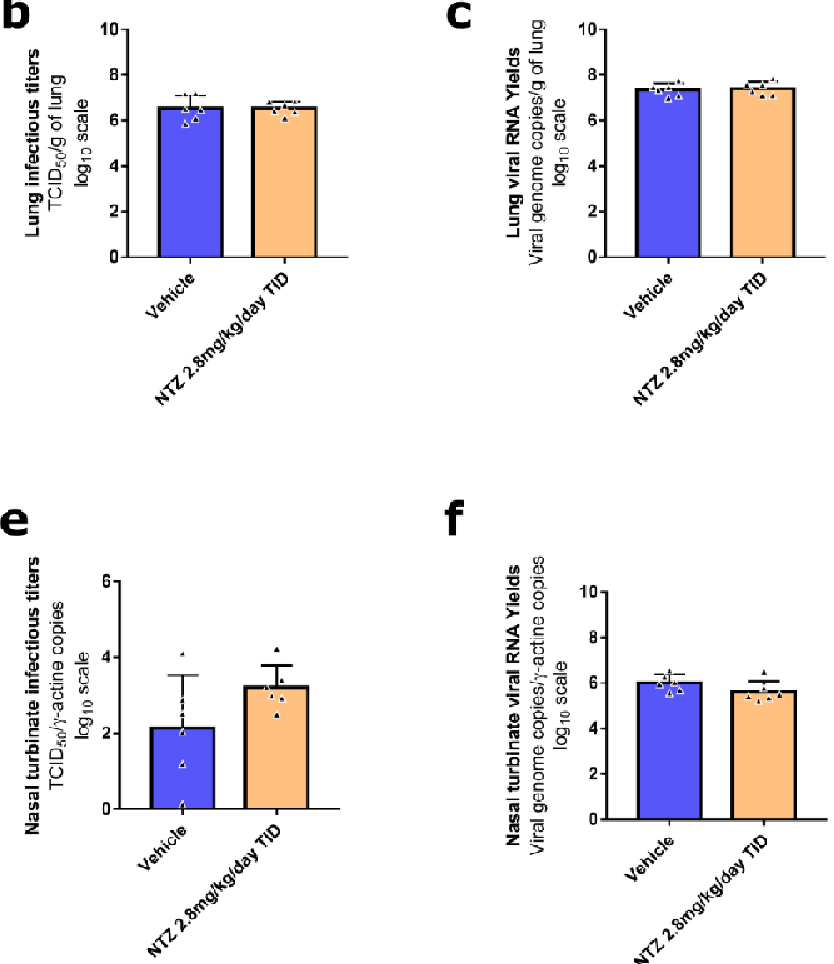

f

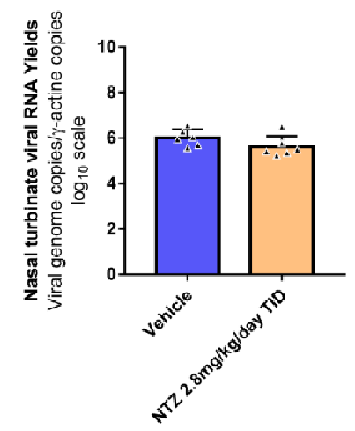

d

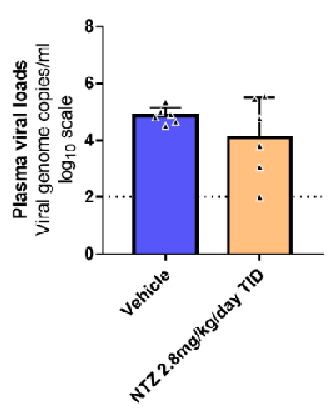

g

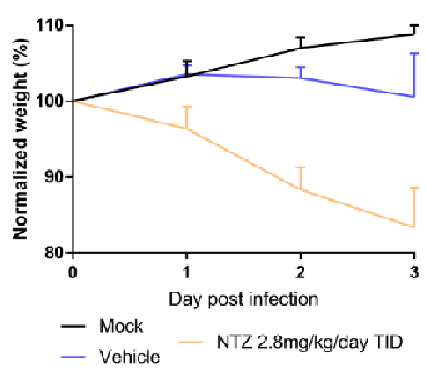

596
Supplementary Fig. 2: Antiviral activity of intranasal treatment of NTZ in a hamster model.

Groups of 6 hamsters were intranasally infected with $10^{4} \mathrm{TCID}_{50}$ of virus. a Experimental timeline. $\mathbf{b}$ Viral replication in lung based on infectious titers (measured using a $\mathrm{TCID}_{50}$ assay) expressed in $\mathrm{TCID}_{50} / \mathrm{g}$ of lung ( $\mathrm{n}=6$ animals/group). $\mathbf{c}$ Viral replication in lung based on viral RNA yields (measured using an RT-qPCR assay) expressed in viral genome copies/g of lung ( $n=6$ animals/group). $\mathbf{d}$ Plasma viral loads (measured using an RT-qPCR assay) are expressed in viral genome copies $/ \mathrm{mL}$ of plasma (the dotted line indicates the detection threshold of the assay) ( $n=6$ animals/group). $e$ Viral replication in nasal turbinates based on infectious titers (measured using a $T_{C I D}$ assay) expressed in $T_{C I D}$ /copy of al-actine gene $(n=6$ animals/group). $\mathbf{f}$ Viral replication in nasal turbinates based on viral RNA yields (measured using an RT-qPCR assay) expressed in viral genome copies/copy of -actine gene ( $n=6$ animals/group). $\mathbf{g}$ Clinical course of the disease $(n=6$ animals/group). Normalized weight at day $n$ was calculated as follows: $\%$ of initial weight of the animal at day $n$. Data represent mean \pm SD (Details in Supplementary Data 1 ). ${ }^{* *}$ symbols indicate that the average value for the group is significantly lower than that of the untreated group with a $p$-value ranging between 0.001-0.01 (Details in Supplementary Data 1). 
bioRxiv preprint doi: https://doi.org/10.1101/2021.12.17.473113; this version posted December 20, 2021. The copyright holder for this preprint (which was not certified by peer review) is the author/funder, who has granted bioRxiv a license to display the preprint in perpetuity. It is made available under aCC-BY 4.0 International license.

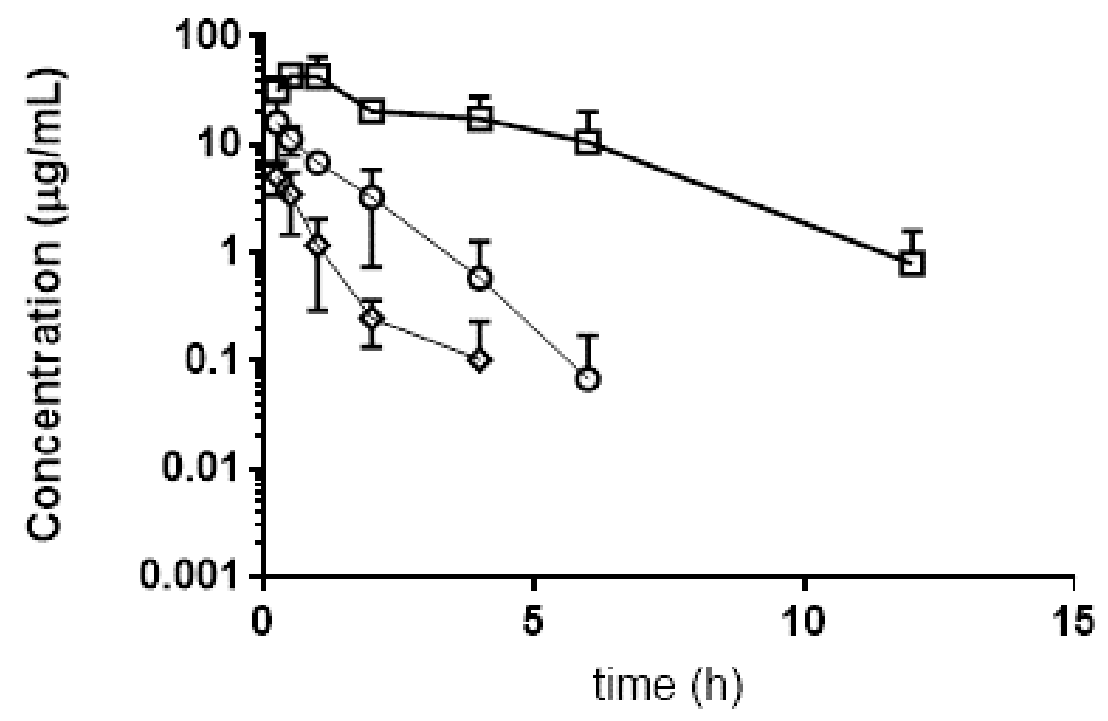

610

611 Supplementary Fig. 3: Plasma concentration of TIZ following administration of NTZ to hamsters at doses of $485 \mathrm{mg} / \mathrm{kg}$ (国),

$61298.1 \mathrm{mg} / \mathrm{kg}$ (回) and $25.5 \mathrm{mg} / \mathrm{kg}$. Three animals per dose group were included error bars represent the standard deviation. 
bioRxiv preprint doi: https://doi.org/10.1101/2021.12.17.473113; this version posted December 20, 2021. The copyright holder for this preprint (which was not certified by peer review) is the author/funder, who has granted bioRxiv a license to display the preprint in perpetuity. It is made available under aCC-BY 4.0 International license.

(A)

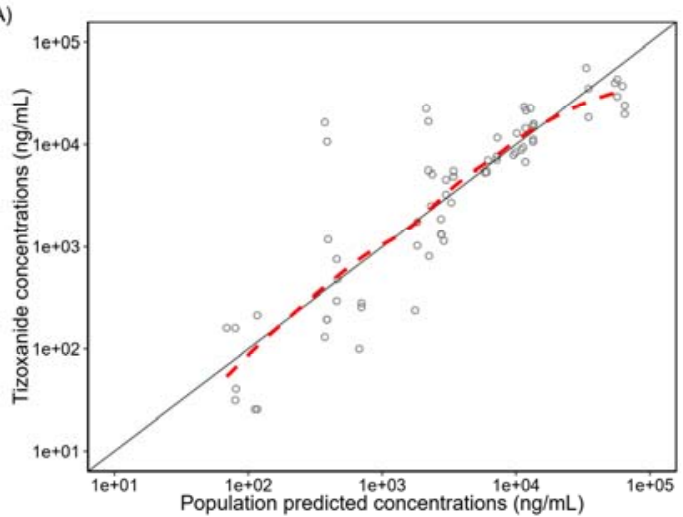

(C)

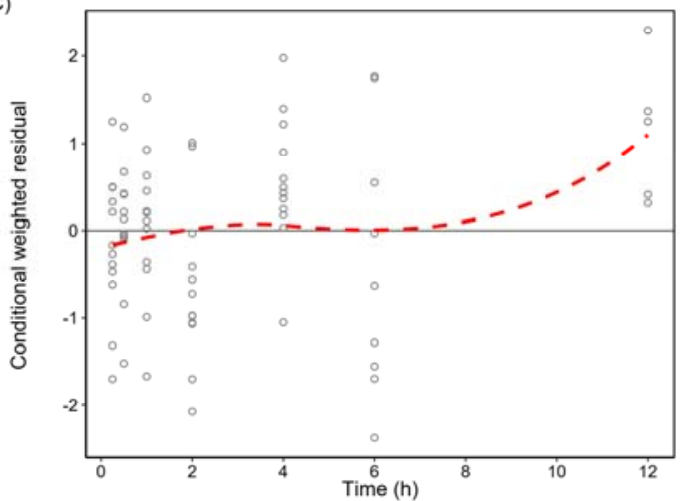

(B)

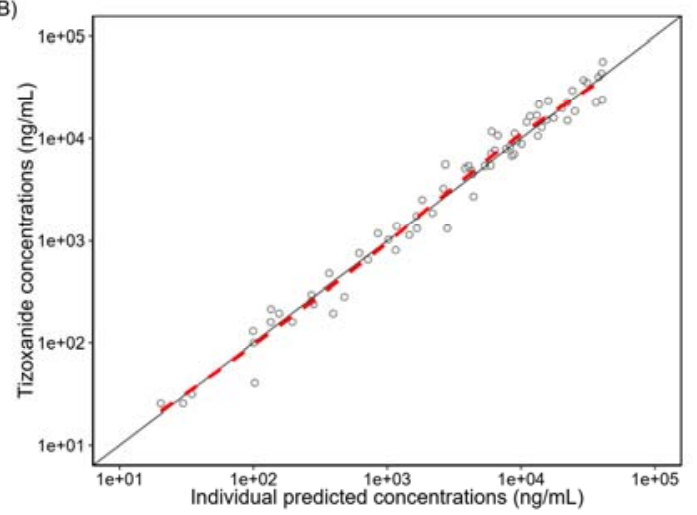

(D)

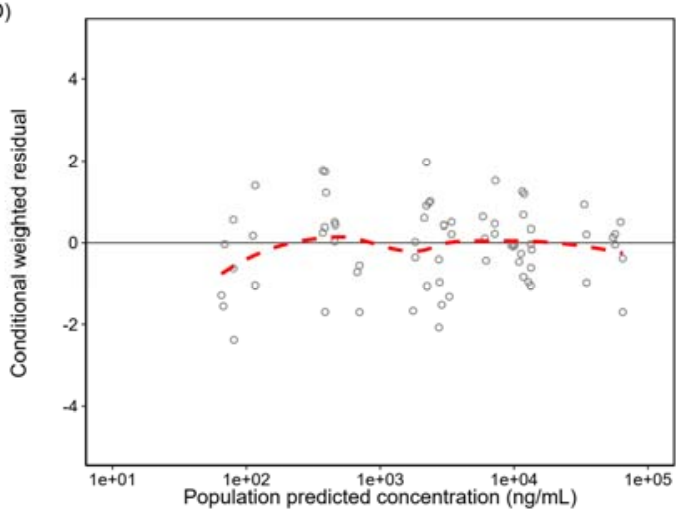

Supplementary Fig. 4: Goodness-of-fit diagnostics of final nitazoxanide population pharmacokinetic model in hamster. (A) Observed tizoxanide concentrations vs population predictions, (B) observed tizoxanide concentrations vs in dividually predicted concentrations, (C) conditionally weighted residual vs time, and (D) conditionally weighted residual vs population predictions. The open circles represent the observed tizoxanide concentrations. The solid black lines represent the line of identity and the dashed red lines represent a local polynomial regression fitting of all observations (i.e. trend line). 
bioRxiv preprint doi: https://doi.org/10.1101/2021.12.17.473113; this version posted December 20,2021 . The copyright holder for this preprint (which was not certified by peer review) is the author/funder, who has granted bioRxiv a license to display the preprint in perpetuity. It is made available under aCC-BY 4.0 International license.

619

\begin{tabular}{|l|c|c|c|c|c|}
\hline & $\begin{array}{c}\text { Time post- } \\
\text { treatment }\end{array}$ & $\begin{array}{c}\text { Plasma } \\
(\mu \mathrm{g} / \mathrm{mL})\end{array}$ & Lung $(\mu \mathrm{g} / \mathrm{g})$ & L/p ratio & $\begin{array}{c}\text { Nasal turbinates } \\
(\mu \mathrm{g} / \mathrm{mL})\end{array}$ \\
\hline Multiple Dose $: 2.8 \mathrm{mg} / \mathrm{kg} / \mathrm{day}$ TID (at 3 dpi) & 12 hours & $\begin{array}{c}0.01 \mathrm{f} \\
(0.03 \mu \mathrm{M})\end{array}$ & $\begin{array}{c}0.10 ; 0.11 \$ \\
(0.39 ; 0.41 \mu \mathrm{M} / \mathrm{g})\end{array}$ & 1279.5 & $\begin{array}{c}0.01 \mathrm{f} \\
(0.06 \mu \mathrm{M})\end{array}$ \\
\hline
\end{tabular}

620 Supplementary Table 1: Plasma lung and nasal turbinates concentrations of TIZ after administration of multiple dose of NTZ. PK realized after 3 days of nitazoxanide administered three times a day, at the end of the dosing interval (trough concentrations). Data represent individual values (Details in Supplementary Data 4). Symbols $\$$ and $f$ represent respectively 4 or 5 values below the limit of quantification. 
bioRxiv preprint doi: https://doi.org/10.1101/2021.12.17.473113; this version posted December 20, 2021. The copyright holder for this preprint (which was not certified by peer review) is the author/funder, who has granted bioRxiv a license to display the preprint in perpetuity. It is made available under aCC-BY 4.0 International license.

624

625

626

627

628

629

630

631

632

\begin{tabular}{|c|c|c|c|c|}
\hline Parameter & $\begin{array}{l}\text { Population estimates }^{a} \\
\qquad(\% \mathrm{RSE})^{\mathrm{b}}\end{array}$ & $95 \% \mathrm{Cl}^{\mathrm{b}}$ & $\begin{array}{l}\text { IIV }^{a}[\% C V] \\
(\% \mathrm{RSE})^{b}\end{array}$ & $95 \% \mathrm{Cl}^{b}$ \\
\hline$F$ & 1 (fixed) & - & - & - \\
\hline $\mathrm{CL} / \mathrm{F}(\mathrm{L} / \mathrm{h})$ & 0.651 (11.9) & $0.504-0.866$ & $40.9(26.5)$ & $14.8-53.5$ \\
\hline $\mathrm{V} / \mathrm{F}(\mathrm{L})$ & $0.128(48.3)$ & $0.044-0.359$ & - & - \\
\hline $\mathrm{Q} / \mathrm{F}(\mathrm{L} / \mathrm{h})$ & $0.391(73.5)$ & $0.134-1.373$ & $55.7(156)$ & $26.8-220$ \\
\hline VP/F (L) & $0.262(32.5)$ & $0.120-0.426$ & - & - \\
\hline$k_{a}\left(h^{-1}\right)$ & $1.74(56.2)$ & $0.941-5.945$ & $99.6(33.4)$ & $40.8-267$ \\
\hline$\sigma$ & 0.151 & $0.088-0.204$ & - & - \\
\hline
\end{tabular}

Supplementary Table 2: Population pharmacokinetic parameters from the final model of NTZ in hamster.

a Population mean values, inter-individual variability (IIV) were estimated by NONMEM. The coefficient of variation (\%CV) for IIV were calculated as $100 \times \sqrt{\operatorname{exp(estimate)~}-1}$.

${ }^{b}$ Relative standard error (\%RSE) was calculated as $100 \times\left(\frac{\text { SD }}{\text { Mean value }}\right)$ from the non-parametric bootstrap results $(n=1,000)$. The $95 \%$ confidence interval $(95 \% \mathrm{Cl})$ is presented as the 2.5 to 97.5 percentiles of bootstrap estimates.

(F : bioavailability ; $\mathrm{CL} / \mathrm{F}$ : oral clearance ; $\mathrm{V} / \mathrm{F}$ : volume of distribution of the central compartment ; $\mathrm{Q} / \mathrm{F}$ : intercompartmental clearance $; \mathrm{VP} / \mathrm{F}:$ volume of distribution of peripheral compartment $; \mathrm{K}_{\mathrm{a}}$ : absorption rate constant ; $\sigma$ : 


\begin{tabular}{|c|c|c|c|}
\hline Gene Target & Primer and probes sequences & $\begin{array}{l}\text { Amplicon } \\
\text { length }\end{array}$ & Reference \\
\hline $\begin{array}{l}\text { Sars-CoV-2 RNA-dependent } \\
\text { RNA polymerase }\end{array}$ & $\begin{array}{c}\text { Fwd: 5'-GTGARATGGTCATGTGTGGCGG-3' } \\
\text { Rev: 5'-CARATGTTAAASACACTATTAGCATA-3' } \\
\text { Probe: 5'-FAM-CAGGTGGAACCTCATCAGGAGATGC-TAMRA-3' }\end{array}$ & $99 \mathrm{pb}$ & $\begin{array}{c}\text { Detection of } 2019 \text { novel coronavirus (2019-nCoV) by real- } \\
\text { time RT-PCR (Corman et al.) }\end{array}$ \\
\hline Syrian hamster $\gamma$-actin & $\begin{array}{c}\text { Fwd: 5'-ACAGAGAGAAGATGACGCAGATAATG-3' } \\
\text { Rev: 5'-GCCTGAATGGCCACGTACA-3' } \\
\text { Probe: 5'-FAM-TTGAAACCTTCAACACCCCAGCC-TAMRA-3' }\end{array}$ & $70 \mathrm{pb}$ & $\begin{array}{l}\text { Duplex real-time reverse transcriptase PCR to determine } \\
\text { cytokine mRNA expression in a hamster model of New } \\
\text { World cutaneous leishmaniasis (Espitita et al.) }\end{array}$ \\
\hline Bacteriophage MS2 & $\begin{array}{c}\text { Fwd: 5'-CTCTGAGAGCGGCTCTATTGGT-3' } \\
\text { Rev: 5'-GTTCCCTACAACGAGCCTAAATTC-3' } \\
\text { Probe: 5'-VIC-TCAGACACGCGGTCCGCTATAACGA-TAMRA-3' }\end{array}$ & $100 \mathrm{pb}$ & $\begin{array}{l}\text { RNA and DNA Bacteriophages as Molecular Diagnosis } \\
\text { Controls in Clinical Virology: A Comprehensive Study of } \\
\text { More than 45,000 Routine PCR Tests (Ninove et al.) }\end{array}$ \\
\hline
\end{tabular}

633

634 Supplementary Table 3: (RT)-qPCR systems. 


\begin{tabular}{|c|c|c|c|}
\hline Lesion & Description & Intensity & Score \\
\hline \multirow{4}{*}{ Interstitial pneumonia } & $\begin{array}{l}1 \text { o } 2 \text { foci with 10-20 cells or small area with two-fold thickening of alveolar } \\
\text { septa }\end{array}$ & Mild & 1 \\
\hline & $\begin{array}{c}3 \text { to } 5 \text { foci with 10-30 cells or widespread areas with two-fold thickening of } \\
\text { alveolar septa }\end{array}$ & Moderate & 2 \\
\hline & $\begin{array}{c}5 \text { foci of } 10-50 \text { cells or widespread areas with two-fold or three-fold thickening } \\
\text { of alveolar septa throughout the lung }\end{array}$ & Marked & 3 \\
\hline & $\begin{array}{l}5 \text { foci of 10-100 cells or widespread areas with three to fourfold-thickened } \\
\text { alveolar septa throughout the lung }\end{array}$ & Severe & 4 \\
\hline \multirow{4}{*}{ Bronchitis } & $\begin{array}{l}1 \text { or } 2 \text { bronchi section(s) filled with rare necrotic/inflammatory cells or partially } \\
\text { surrounded by scarce inflammatory cells }\end{array}$ & Mild & 1 \\
\hline & $\begin{array}{l}3 \text { to } 5 \text { bronchi filled with necrotic/inflammatory cells or partially surrounded by } \\
\qquad \text { a few inflammatory cells }\end{array}$ & Moderate & 2 \\
\hline & $\begin{array}{l}6 \text { to } 10 \text { bronchi filled with necrotic/inflammatory cells, partially or sub- } \\
\text { completely surrounded by inflammatory cells }\end{array}$ & Marked & 3 \\
\hline & $\begin{array}{l}\text { Numerous bronchi filled with inflammatory or cellular debris or completely } \\
\text { surrounded by numerous inflammatory cells }\end{array}$ & Severe & 4 \\
\hline \multirow{2}{*}{ Endothelitis, vasculitis } & Absent & - & 0 \\
\hline & Present & - & 1 \\
\hline \multirow{3}{*}{ Hemorrhagic necrosis } & Absent & - & 0 \\
\hline & Focal to multifocal & Mild to moderate & 1 \\
\hline & Coalescing to extensive necrosis & Severe & 2 \\
\hline
\end{tabular}


bioRxiv preprint doi: https://doi.org/10.1101/2021.12.17.473113; this version posted December 20,2021 . The copyright holder for this preprint (which was not certified by peer review) is the author/funder, who has granted bioRxiv a license to display the preprint in perpetuity. It is made available under aCC-BY 4.0 International license.

637

\begin{tabular}{|l|l|l|}
\hline Cumulative score & Grade & Bronchointerstitial pneumonia \\
\hline 0 & 0 & Normal \\
\hline $1-3$ & 1 & Mild \\
\hline $4-5$ & 2 & Moderate \\
\hline $6-8$ & 3 & Marked \\
\hline $9-10$ & 4 & Severe \\
\hline
\end{tabular}

638 Supplementary Table 5: Histopathological lung inflammation semi-quantitative grading 


\section{References}

640

641

642

643

644

645

646

647

648

649

650

651

652

653

654

655

656

657

658

659

660

661

662

663

664

665

666

667

668

669

670

671

672

673

674

675

676

677

678

679

680

681

682

683

684

685

686

687

688

1. Zhu N, Zhang D, Wang W, Li X, Yang B, Song J, et al. A Novel Coronavirus from Patients with Pneumonia in China, 2019. N Engl J Med. 2020;382(8):727-33.

2. Zhou P, Yang XL, Wang XG, Hu B, Zhang L, Zhang W, et al. A pneumonia outbreak associated with a new coronavirus of probable bat origin. Nature. 2020;579(7798):270-3.

3. WHO. World Health Organization. WHO Director-General's opening remarks at the media briefing on COVID-19 - 11 March 20202020 [Available from: https://www.who.int/directorgeneral/speeches/detail/who-director-general-s-opening-remarks-at-the-media-briefing-on-covid19---11-march-2020.

4. Le Bert N, Tan AT, Kunasegaran K, Tham CYL, Hafezi M, Chia A, et al. SARS-CoV-2-specific T cell immunity in cases of COVID-19 and SARS, and uninfected controls. Nature. 2020;584(7821):45762.

5. Kratky M, Vinsova J. Antiviral activity of substituted salicylanilides--a review. Mini Rev Med Chem. 2011;11(11):956-67.

6. Rossignol JF. Nitazoxanide: a first-in-class broad-spectrum antiviral agent. Antiviral Res. 2014;110:94-103.

7. Cao J, Forrest JC, Zhang X. A screen of the NIH Clinical Collection small molecule library identifies potential anti-coronavirus drugs. Antiviral Res. 2015;114:1-10.

8. Stachulski AV, Taujanskas J, Pate SL, Rajoli RKR, Aljayyoussi G, Pennington SH, et al. Therapeutic Potential of Nitazoxanide: An Appropriate Choice for Repurposing versus SARS-CoV-2? ACS Infect Dis. 2021;7(6):1317-31.

9. Beigel JH, Nam HH, Adams PL, Krafft A, Ince WL, El-Kamary SS, et al. Advances in respiratory virus therapeutics - A meeting report from the 6th isirv Antiviral Group conference. Antiviral Res. 2019;167:45-67.

10. Rossignol JF. Nitazoxanide, a new drug candidate for the treatment of Middle East respiratory syndrome coronavirus. J Infect Public Heal. 2016;9(3):227-30.

11. Rossignol JF, La Frazia S, Chiappa L, Ciucci A, Santoro MG. Thiazolides, a New Class of Antiinfluenza Molecules Targeting Viral Hemagglutinin at the Post-translational Level. Journal of Biological Chemistry. 2009;284(43):29798-808.

12. Belardo G, Cenciarelli O, La Frazia S, Rossignol JF, Santoro MG. Synergistic effect of nitazoxanide with neuraminidase inhibitors against influenza $A$ viruses in vitro. Antimicrob Agents Chemother. 2015;59(2):1061-9.

13. Martins PR, Barreto-Alves JA, Fakhouri R. Potential role for nitazoxanide in treating SARSCoV-2 infection. Am J Physiol-Lung C. 2020;319(1):L35-L6.

14. Chibber P, Haq SA, Ahmed I, Andrabi NI, Singh G. Advances in the possible treatment of COVID-19: A review. Eur J Pharmacol. 2020;883.

15. Alonso DF, Farina HG. Repurposing of host-based therapeutic agents for the treatment of coronavirus disease 2019 (COVID-19): a link between antiviral and anticancer mechanisms? Int J Antimicrob Agents. 2020;56(3):106125.

16. Dos Santos WG. Natural history of COVID-19 and current knowledge on treatment therapeutic options. Biomed Pharmacother. 2020;129:110493.

17. Yang CW, Peng TT, Hsu HY, Lee YZ, Wu SH, Lin WH, et al. Repurposing old drugs as antiviral agents for coronaviruses. Biomed J. 2020;43(4):368-74.

18. Arshad U, Pertinez H, Box H, Tatham L, Rajoli RK, Curley P, et al. Prioritisation of potential anti-SARS-CoV-2 drug repurposing opportunities based on ability to achieve adequate plasma and target site concentrations derived from their established human pharmacokinetics. medRxiv. 2020:2020.04.16.20068379.

19. Wang $M$, Cao R, Zhang L, Yang X, Liu J, Xu M, et al. Remdesivir and chloroquine effectively inhibit the recently emerged novel coronavirus (2019-nCoV) in vitro. Cell Res. 2020;30(3):269-71. 
689 20. Lokhande AS, Devarajan PV. A review on possible mechanistic insights of Nitazoxanide for 690 repurposing in COVID-19. Eur J Pharmacol. 2021;891:173748.

691 21. Braga L, Ali H, Secco I, Chiavacci E, Neves G, Goldhill D, et al. Drugs that inhibit TMEM16 692 proteins block SARS-CoV-2 spike-induced syncytia. Nature. 2021;594(7861):88-93.

693 22. Driouich J-S, Cochin M, Lingas G, Moureau G, Touret F, Petit PR, et al. Favipiravir antiviral 694 efficacy against SARS-CoV-2 in a hamster model. bioRxiv. 2020:2020.07.07.191775.

695 23. Touret $F$, Driouich J-S, Cochin M, Rémi Petit P, Gilles M, Barthélémy K, et al. Preclinical 696 evaluation of Imatinib does not support its use as an antiviral drug against SARS-CoV-2. bioRxiv. 697 2020:2020.11.17.386904.

698 24. Touret F, Gilles M, Barral K, Nougairede A, van Helden J, Decroly E, et al. In vitro screening of 699 a FDA approved chemical library reveals potential inhibitors of SARS-CoV-2 replication. Sci Rep. 700 2020;10(1):13093.

701 25. Touret F, Baronti C, Goethals O, Van Loock M, de Lamballerie X, Querat G. Phylogenetically 702 based establishment of a dengue virus panel, representing all available genotypes, as a tool in 703 dengue drug discovery. Antiviral Res. 2019;168:109-13.

704 26. Pizzorno A, Padey B, Julien T, Trouillet-Assant S, Traversier A, Errazuriz-Cerda E, et al. 705 Characterization and Treatment of SARS-CoV-2 in Nasal and Bronchial Human Airway Epithelia. Cell 706 Rep Med. 2020;1(4):100059.

707 27. Chan JF, Zhang AJ, Yuan S, Poon VK, Chan CC, Lee AC, et al. Simulation of the Clinical and 708 Pathological Manifestations of Coronavirus Disease 2019 (COVID-19) in a Golden Syrian Hamster 709 Model: Implications for Disease Pathogenesis and Transmissibility. Clin Infect Dis. 2020;71(9):2428repurposing nitazoxanide in SARS-CoV-2 treatment or chemoprophylaxis. $\mathrm{Br} J$ Clin Pharmacol. 2021;87(4):2078-88.

29. Broekhuysen J, Stockis A, Lins RL, De Graeve J, Rossignol JF. Nitazoxanide: pharmacokinetics and metabolism in man. Int J Clin Pharmacol Ther. 2000;38(8):387-94.

30. Elazar M, Liu M, McKenna SA, Liu P, Gehrig EA, Puglisi JD, et al. The anti-hepatitis C agent nitazoxanide induces phosphorylation of eukaryotic initiation factor 2alpha via protein kinase activated by double-stranded RNA activation. Gastroenterology. 2009;137(5):1827-35.

31. Braga L, Ali H, Secco I, Chiavacci E, Neves G, Goldhill D, et al. Drugs that inhibit TMEM16 proteins block SARS-CoV-2 spike-induced syncytia. Nature. 2021.

32. Walsh KF, McAulay K, Lee MH, Vilbrun SC, Mathurin L, Jean Francois D, et al. Early Bactericidal Activity Trial of Nitazoxanide for Pulmonary Tuberculosis. Antimicrob Agents Chemother. 2020;64(5).

33. Rossignol J-F, Matthew CB, Oaks JB, Bostick BG, Vora KN, Fulgencio J, et al. Early treatment with nitazoxanide prevents worsening of mild and moderate COVID-19 and subsequent hospitalization. medRxiv. 2021:2021.04.19.21255441.

34. Gupta A, Tulsankar SL, Bhatta RS, Misra A. Pharmacokinetics, Metabolism, and Partial Biodistribution of "Pincer Therapeutic" Nitazoxanide in Mice following Pulmonary Delivery of Inhalable Particles. Mol Pharm. 2017;14(4):1204-11.

35. Delang L, Li C, Tas A, Querat G, Albulescu IC, De Burghgraeve T, et al. The viral capping enzyme nsP1: a novel target for the inhibition of chikungunya virus infection. Sci Rep-Uk. 2016;6.

36. Reed LaMH. A simple method of estimating fifty per cent endpoint. American Journal of Epidemiology. 1938;27 (3):493-7.

37. Harausz EP, Chervenak KA, Good CE, Jacobs MR, Wallis RS, Sanchez-Felix M, et al. Activity of nitazoxanide and tizoxanide against Mycobacterium tuberculosis in vitro and in whole blood culture. Tuberculosis (Edinb). 2016;98:92-6.

38. Balderas-Acta Jl, Ríos-Rogríguez Bueno EP, Pérez-Becerril F, Espinosa-Martínez C, Burke-Fraga V, González-de la Parra G. Bioavailability of Two Oral-Suspension Formulations of a Single Dose of Nitazoxanide 500 mg: An Open-Label, Randomized-Sequence, Two-Period Crossover, Comparison in Healthy Fasted Mexican Adult Volunteers. J Bioequiv Availab. 2011;3(3):043-7. 
bioRxiv preprint doi: https://doi.org/10.1101/2021.12.17.473113; this version posted December 20, 2021. The copyright holder for this preprint (which was not certified by peer review) is the author/funder, who has granted bioRxiv a license to display the preprint in perpetuity. It is made available under aCC-BY 4.0 International license.

39. Lavielle M. mlxR: Simulation of Longitudinal Data. 2017.

742 